NBER WORKING PAPER SERIES

SOVEREIGN DEBT RISK PREMIA AND FISCAL POLICY IN SWEDEN

\author{
Huixin Bi \\ Eric M. Leeper \\ Working Paper 15810 \\ http://www.nber.org/papers/w15810
}

NATIONAL BUREAU OF ECONOMIC RESEARCH
1050 Massachusetts Avenue
Cambridge, MA 02138
March 2010

Prepared for the Swedish Fiscal Policy Council meeting in June 2010. We thank the Swedish Ministry of Finance for providing us with the data used in this paper and Lars Calmfors for comments that improved the paper's exposition. Bi: Department of Economics, Indiana University, hbi@indiana.edu; Leeper: Department of Economics, Indiana University and NBER, eleeper@indiana.edu The views expressed herein are those of the authors and do not necessarily reflect the views of the National Bureau of Economic Research.

NBER working papers are circulated for discussion and comment purposes. They have not been peerreviewed or been subject to the review by the NBER Board of Directors that accompanies official NBER publications.

(C) 2010 by Huixin Bi and Eric M. Leeper. All rights reserved. Short sections of text, not to exceed two paragraphs, may be quoted without explicit permission provided that full credit, including (C notice, is given to the source. 
Sovereign Debt Risk Premia and Fiscal Policy in Sweden

Huixin Bi and Eric M. Leeper

NBER Working Paper No. 15810

March 2010, Revised March 2010

JEL No. E6,E62,H2,H5,H6

\section{ABSTRACT}

This paper takes a step toward providing a general equilibrium framework within which to study the nub of the current fiscal debate around the world: what are the tradeoffs between short-run stabilization and long-run sustainability when the perceived riskiness of government debt depends, in part, on the current and expected fiscal environment in place? We calibrate a simple model to Swedish fiscal data in two periods: before and after the financial crisis of the early 1990s. We compute the dynamic fiscal limit, which depends on the peak of the Laffer curve, for the pre-crisis and three alternative post-crisis fiscal policies. The model simulates the macroeconomic consequences of alternative policies in the face of the sequence of bad output shocks that Sweden experienced from 1991-1997.

\section{Huixin Bi}

Department of Economics

304 Wylie Hall

Indiana University

Bloomington, IN 47405

hbi@indiana.edu

Eric M. Leeper

Department of Economics

304 Wylie Hall

Indiana University

Bloomington, IN 47405

and NBER

eleeper@indiana.edu 


\title{
Sovereign Debt Risk Premia and Fiscal Policy in Sweden*
}

\author{
Huixin Bi and Eric M. Leeper
}

\section{InTRODUCTION}

The current worldwide recession has brought with it a chorus of calls from economists for substantial fiscal stimulus. Along with this chorus has been a discordant cry for fiscal discipline. In few countries has the ensemble of fiscal policy debate been more apparent than in Sweden. One side of the debate has been represented by the Swedish Fiscal Policy Council's (2009b, p. 1) annual report, which stated: "The large downward revisions of economic forecasts since the Budget Bill justifies, in our opinion, stronger stimulus measures this year than those taken up to now," and "Additional stimulus measures beyond those announced by the Government should probably be taken in 2010." The government's response was that Sweden's fiscal system has strong automatic stabilizers that ensure a substantial fiscal stimulus in response to the recession. Moreover, in light of such strong automatic stabilizers, additional discretionary stimulus could endanger Sweden's one percent surplus target, threatening fiscal credibility [Swedish Ministry of Finance (2009); Borg (2009)]. Incredible fiscal policies could induce financial markets to penalize Sweden by attaching risk premia to its sovereign debt, in a rerun of the 1990s.

A similar debate is playing out around the world as governments struggle to find an appropriate fiscal response to the recession. Most countries, though, do not have Sweden's fiscal policy infrastructure, which serves to institutionalize public fiscal discourse. The combination of explicit rules to guide fiscal decisions and an independent fiscal council with

*March 15, 2010. Prepared for the Swedish Fiscal Policy Council meeting in June 2010. We thank the Swedish Ministry of Finance for providing us with the data used in this paper and Lars Calmfors for comments that improved the paper's exposition. Bi: Department of Economics, Indiana University, hbi@indiana.edu; Leeper: Department of Economics, Indiana University and NBER, eleeper@indiana.edu 
access to the Parliament provides a context that makes the ground in Sweden especially fertile for constructive debate.

American fiscal policy provides a sharp contrast. Despite its current record budget deficits and long-term projections that imply current policy is unsustainable, fiscal discussions are dominated by politics, with little serious economic analysis to buttress the arguments. ${ }^{1}$ American fiscal decisions are not guided by any obvious economically based rules and what "rules" do exist are easily circumvented by the political process or accounting tricks. In principle, serious analysis is provided by the Congressional Budget Office (CBO). In practice, the CBO's leadership is chosen by the majority party in Congress, an institutional feature that is not conducive to encouraging independent and critical analysis of fiscal proposals and decisions.

One reason for the sharp differences in fiscal policy infrastructure across the two countries is that the United States has no fresh memory of fiscal crises that called into question the "risklessness" of its central government debt. Sweden has such a memory: as recently as 1993, Swedish debt was downgraded in the aftermath of Sweden's worst banking crisis in the post-World War II period. Out of that crisis grew Sweden's current monetary and fiscal policy framework, an important element of which is transparency and open debate about macroeconomic policies.

This paper takes a step toward providing a general equilibrium framework within which to study the nub of the current fiscal debate around the world: what are the tradeoffs between short-run stabilization and long-run sustainability when the perceived riskiness of government debt depends, in part, on the fiscal environment in place?

We employ a simple dynamic stochastic general equilibrium model similar to Bi's (2009) in which the government finances spending and lump-sum transfers with a distorting income tax and debt. Sovereign debt, however, need not be risk-free. Distorting taxes imply that there are limits to the government's ability to raise revenues because higher tax rates create disincentives to work that counteract the positive revenue effects of the higher rates. The resulting dynamic Laffer curve generates a distribution for the economy's fiscal limit. Even if the government is able to raise revenues, it may not be willing to do so. We treat that willingness as a political decision that is unrelated to the economic fundamentals. Each period an effective fiscal limit is realized as a draw from the fiscal limit distribution. If outstanding debt exceeds the effective limit, the government (partially) defaults on its obligations. Forward-looking economic agents forecast the probability of default at some point in the future and factor that probability into their decisions.

We calibrate the model to Swedish fiscal data in two periods: before and after the financial

\footnotetext{
${ }^{1}$ See Congressional Budget Office $(2009 \mathrm{a}, \mathrm{b})$ for some fiscal accounting exercises.
} 
crisis of the early 1990s. Before the crisis, transfers and average tax rates were higher than they have been since the crisis. In addition, government spending seems to have changed from being countercyclical before the crisis to procyclical after the crisis. We compute the dynamic fiscal limit for the pre-crisis and three alternative post-crisis fiscal policies. The alternative policies include ones that Sweden has implemented - a smaller government size, as measured by the share of transfers and revenues in GDP; a change to procyclical government spending; the imposition of a ceiling on government expenditures, the sum of spending and transfers. The model simulates the macroeconomic consequences of alternative policies in the face of the sequence of bad output shocks that Sweden experienced from 1991-1997.

Our approach begins to fill a critical hole in the literature. Because fiscal policies are typically evaluated in structural models that do not allow for the possibility of sovereign debt default, those evaluations are unreliable when applied to economies where financial markets regard government debt as risky. ${ }^{2}$ Given Sweden's experience in the 1990s, it is clear that treating Swedish government debt at "risk-free" in all states of the world could produce profoundly misleading conclusions.

This paper differs from the literature of strategic default that has grown out of the early papers by Eaton and Gersovitz (1981) and Eaton et al. (1986). Those authors model default on external debt as an optimal and strategic decision made by the government, which emphasizes the willingness of the government to service its debt. A large literature on international borrowing in emerging markets has expanded on this approach [see, for example, Arellano (2008), Aguiar and Gopinath (2006), Mendoza and Yue (2008)]. However, that literature makes predictions that are sharply at odds with data: either the default frequency is far too high or the level of debt at which default occurs is far too low. Although efforts to model default as a strategic decision are well meaning, they are unlikely in their current form to shed useful light on the current fiscal policy debates.

A key conclusion emerges from our analysis: the right kinds of fiscal reforms - specifically, the adoption of certain classes of fiscal rules - can shift the economy's fiscal limit in important ways and dramatically reduce the likelihood that sovereign debt will be assessed a risk premium, even in the face of bad economic shocks like those that hit Sweden in the 1990s. Concluding remarks discuss useful extensions to the analysis that would allow a richer set of conclusions to be drawn.

\footnotetext{
${ }^{2}$ Examples of the typical fiscal analyses abound. Here are a few: Romer and Bernstein (2009), Cogan et al. (2009), Cwik and Wieland (2009), Eggertsson (2009), Christiano et al. (2009), Davig and Leeper (2009), Uhlig (2009), Leeper et al. (2009), Coenen et al. (2009).
} 


\section{The Early 1990s: Impetus to Policy Reform}

In the early 1990s Sweden experienced a boom-bust cycle that severely tested the prevailing monetary-fiscal policy regime. ${ }^{3}$ After deregulation of the financial system, the economy boomed in the late 1980s, with rapid growth in GDP, employment, consumption, and imports. Despite a worsening current account balance, monetary policy was prevented from reacting to the boom because the krona was pegged to a basket of currencies.

By 1989-1990 the boom had ended and the bust began. Rising international real interest rates exerted further pressure on the pegged krona while simultaneously the Riksbank raised nominal interest rates to defend the krona against speculative attacks. Major tax reform in 1990-1991 sharply lowered marginal tax rates and reduced mortgage deductibility, raising real after-tax interest rates still more. The strong increases in real rates deflated asset values, which reduced wealth and triggered a banking crisis.

The resulting recession was comparable to Sweden's experience in the Great Depression. GDP fell for three consecutive years. Unemployment rose from 1.5 percent in 1989 to over 8 percent in 1993. The cumulative employment loss exceeded that of the Great Depression, on the order of 16 percent, according to Jonung and Hagberg (2005) and Jonung (2009). Attacks on the krona continued, culminating in the famous instance on September 16, 1992 when the Riksbank raised the overnight rate to 500 percent. ${ }^{4}$ In the event, by November 19 the Riksbank allowed the krona to float.

Large automatic stabilizers built into Swedish fiscal rules swung the general government balance from a 5 percent surplus in 1989 to nearly a 12 percent deficit in $1993 .{ }^{5}$ Central government debt rose from 30 percent to 80 percent of GDP over the same period.

The Swedish government responded with a thorough reform of both monetary and fiscal policy. Beginning in January 1993, the Riksbank announced a 2 percent target for CPI inflation, applying from 1995 on. This target was formalized by the Sveriges Riksbank Act, passed in 1997, an act that greatly reinforced the Riksbank's independence [Sveriges Riksbank (2008)]. Fiscal policy in 1993 consolidated in fits and starts, but projections showed government debt continuing to grow rapidly and fears of sustainability arose. Progress on fiscal reform was motivated by at least three concerns. First, bond markets downgraded Swedish sovereign debt in 1993. Second, by the end of 1993 one-third of government expenditures were devoted to debt service. Third, it was recognized that fiscal instability could undermine the Riksbank's newly adopted inflation targeting regime. A series of bills

\footnotetext{
${ }^{3}$ This section draws liberally from Swedish Ministry of Finance (2001), Jonung and Hagberg (2005), Jonung (2009), Reinhart and Rogoff (2008), and Wetterberg (2009).

${ }^{4}$ The Riksbank had plans to go as high as 4000 percent [Swedish Ministry of Finance (2001)].

${ }^{5}$ Sweden is known for having unusually strong automatic stabilizers [Flodén (2009), Calmfors (2009)].
} 
beginning in late 1994, called the "Consolidation Programme," sought to stabilize debt by adopting both a nominal expenditures ceiling and a surplus target. By 1998 the budget had swung back to surplus and debt was on a downward trajectory.

Jonung (2009) lists macroeconomic policy reforms as critical factors in resolving crises in both the financial sector and the real economy. Swedish policies continue to be guided by the reforms that grew out of the crises.

\section{Empirical Work on Interest Rates and Government Debt}

It is widely known that the empirical literature lacks consensus on the effects of government debt and deficits upon interest rates. Barth et al. (1991) surveys 42 earlier papers through 1989, of which 17 claimed positive effects, 19 showed negative effects, and 6 found mixed effects. Gale and Orszag (2003) review recent studies and conclude that current deficits tend to have a significant impact on interest rates if deficit expectations are incorporated. Canzoneri et al. (2002) use the U.S. Congressional Budget Office's projected surpluses and find that an increase in projected future deficits averaging one percent of current GDP raises the long-term interest rate relative to the short-term rate of 53 to 60 basis points. Laubach (2003) uses projections from CBO and the U.S. Office of Management and Budget and finds that a one percentage point increase in the deficit-to-GDP ratio raises long-term interest rates by 25 basis point. Nevertheless, Engen and Hubbard (2004) claim that a one percent increase in government debt, regardless of whether it is expected or current debt, increases the real interest rate by a trivial 3 basis points.

More recently, Chinn and Frankel (2005) show that current and expected levels of debt do affect long-term interest rates in Europe and the United States, but the estimates are sensitive to the sample period. Ardagna et al. (2007) find that a one percentage point increase in the primary deficit leads to a 10 basis point increase in the long-term rate, while public debt has a nonlinear effect. Ardagna (2009) identifies periods of large fiscal contractions and expansions in OECD countries, and then studies how the large changes affect interest rates. She shows that interest rates fall around episodes of fiscal consolidations and rise around periods of fiscal expansion.

A second line of work focuses on the relationship between default risk premia, instead of interest rates, and fiscal policy. Unfortunately, there is also lack of consensus in these studies. Using the yield on various countries' bonds issued in Deutsche marks, Lønning (2000) finds that yield differentials, despite being very small, are correlated with bond ratings and various macroeconomic variables. Focusing on U.S. data, Dai and Philippon (2006) use an affine-term-structure model and find that a one percent increase in the deficit-to-GDP ratio increases the 10-year rate by 40 to 50 basis points, with half of the increase attributable 
to risk premia. In contrast, Heppke-Falk and Hüfner (2004) estimate a model of France, Germany and Italy and fail to find any significant impact of the expected deficit on the swap spread.

Some papers find that the relationship is both state-specific and country-specific. Alesina et al. (1992) compare 12 OECD countries and find that sovereign default risks are affected by the debt level at high levels of debt, but not influenced by the debt level at low levels of debt. Codogno et al. (2003) find that default risk explains a substantial part of changes in yield spreads in Italy and Spain, but not in other EU countries.

Other studies identify nonlinear relationships. Bayoumi et al. (1995) find a strong nonlinear relationship between municipal bond yields and debt variables for U.S. states. Bernoth et al. (2006) focus on European countries between 1993 and 2005 and find that debt service ratios raise spreads nonlinearly. Haugh et al. (2009) analyze large movements in the sovereign yield spreads between Germany and other European countries in the current financial crisis and find that deteriorations in fiscal performance increase the spread in a nonlinear way.

The relationship between fiscal measures and interest rates is quite complex. It depends on how, when, and why fiscal deficits and debt rise. Traum and Yang (2009) estimate the crowding out effects of government debt in a new Keynesian model. They show that debt expansions induced by higher spending can have very different effects than those induced by lower taxes. There can also be intricate dynamics linking fiscal actions to interest ratesdynamics that are also affected by monetary policy behavior. Finally, it matters a great deal whether the debt expansion arises from an endogenous response of fiscal policy to macroeconomic developments or whether fiscal expansion is exogenous. Reduced-form studies cannot shed light on these critical aspects, which is why the findings reported above are all over the map.

Two broad methodological points emerge from this vast empirical literature. First, the thought experiment that generates the debt expansion must be carefully controlled. This requires explicit economic theory and cannot be achieved through purely empirical analysis, however sophisticated the statistical techniques employed. Second, it is important to allow for possible nonlinearities in the relationship between fiscal policy and interest rates. Below we report a theoretical framework within which these two points are addressed.

\section{Swedish Fiscal Policy}

Even raw time series data on Swedish fiscal variables and real GDP reveal some interesting patterns that are important for our subsequent theoretical analysis. 
4.1 Fiscal Data: 1970 To 2007 Figure 1 plots three fiscal variables as ratios of GDPtransfers, government spending and tax revenues (solid lines, measured on the right axis) against detrended real GDP (dashed lines, measured on the left axis) in the left panel and against the debt-GDP ratio in the right panel. After the initial doubling of the level of transfers in the mid-to-late 1980s, transfers have been largely stable, except for the substantial spike during the early 1990s crisis. Government spending, in contrast, tends to fluctuate quite a bit more. Both transfers and government spending exhibit clear countercyclical patterns, while revenues are procyclical.

Revenues as a share of GDP provide a rough guide to the average tax rate in the economy. The tax rate reached a peak in the late 1980s, then fell steadily for five years, before achieving another peak around 2000. Since then the average level of taxes has declined steadily.

Government debt displays two distinct humps - the first associated with the 1970s runup in transfers and spending and the second associated with the early 1990s crisis. There is some tendency for revenues to adjust with a lag to swings in government debt, as the right panels show. Government spending and transfers, on the other hand, appear to lead movements in debt.

Figure 2 repeats the previous graph, but plots detrended levels of transfers and government spending against detrended real GDP in the left panels and the debt-GDP ratio in the right panels. Detrended transfers steadily increased in 1970s and stayed at high levels in 1980s and early 1990s. After experiencing a large spike in 1992, they have steadily decreased. The cyclicality of detrended government spending differs markedly from the spending-GDP ratio in figure 1: detrended spending is countercyclical before the 1991 crisis and becomes much less countercyclical after (possibly even procyclical). This difference underscores that the spending-GDP ratio may give misleading impressions of the cyclical nature of government spending, as the ratio can rise in recessions even when the level is falling.

Detrended data seem to make the timing relations between fiscal variables and debt more clear. When either detrended transfers or government spending are rising, debt as a share of GDP tends to rise with a lag. This pattern seems to be fairly robust across time. As in the previous figure, tax adjustments tend to follow movements in debt.

In what follows, we shall use these data to calibrate a formal theoretical model of Swedish fiscal behavior.

4.2 Fiscal Rules The fiscal framework was introduced in 1993, when the fiscal deficit reached 12 percent of GDP and total government expenditures reached 60 percent of GDP. ${ }^{6}$

\footnotetext{
${ }^{6}$ Total government expenditure includes both lump-sum transfers - defined as the sum of social security payments, net capital transfers and subsidies - and government purchases - defined as the sum of government final consumption and consumption of fixed capital.
} 
Since then, the Swedish government has been able to reduce public expenditures from 60 percent of GDP in 1993 to 45 percent of GDP in 2007 by reducing social benefits, public subsidies, capital expenditures and public consumption.

Sweden's fiscal framework consists of three components covering both central and local governments, which are summarized in Dumas (2004). First, a ceiling on total expenditures, excluding interest payments, was introduced at the central government level (operational rule) in 1997. The ceilings are set in nominal terms for three years on a rolling basis. ${ }^{7}$ The multi-year budget forecast is updated for the year after the budget year and to add a third year to the projection. ${ }^{8}$ Sweden's Ministry of Finance prepares the budget and presents it to Riksdag (the Parliament), which votes on the expenditure ceiling and how to divide the budget into 27 expenditure areas. The ceiling also includes a reserve for contingencies. Reserves arise when the total amount allocated to expenditure areas falls below the ceiling. In principle, the reserve acts as a "rainy-day fund," to be used during economic downturns when revenues decline sharply. Past practice has sometimes fallen short of this ideal, with reserves used to finance discretionary expenditures.

Second, a budget surplus target has been adopted at the general government level. A target of 1 percent of GDP over the cycle has been chosen to ensure that Sweden's aging population will not cause public finances to deteriorate. The target was changed from 2 percent to 1 percent in 2007 as a response to Eurostat's decision that funded pension systems (such as the Swedish premium pension system) are reported in the household sector, rather than in the general government sector [Lindh and Ljungman (2007)]. It is difficult to operationalize a surplus target, as there is no consensus on how to measure the cyclically adjusted budget balance, so the target is best treated as a medium-term objective [Boije and Fischer (2006a,b)].

Third, a balanced budget at the local government level was introduced in 2000. The local governments' budgets have to be balanced ex ante, meaning that the local government must present a plan to cover the deficit within two years if they are in deficit ex post.

Sovereign debt ratings agencies have endorsed Sweden's fiscal reforms. After the 1993 downgrade of Swedish debt, Standard \& Poor's (1997) revised its long-term foreign currency rating outlook for Sweden from negative to stable, largely due to "expected fiscal strength-

\footnotetext{
${ }^{7}$ Dumas (2004) claims that "the expenditure ceiling is consistent with the budget surplus target," while Ljungman (2008) says that "no explicit principles for calculating the expenditure ceilings are presented." The Swedish Fiscal Policy Council has argued that at the same time that opportunities to circumvent the ceiling should be reduced, there also ought to be well-established escape causes. These changes would enhance the credibility of the ceiling, according to the Council [see Swedish Fiscal Policy Council (2009b,a)].

${ }^{8}$ The macroeconomic assumptions for the fiscal projections are biased downwards in order to limit the risk of excessive optimism about revenues. Savings are intended to be used to reduce debt, but in practice they may be used to increase expenditures.
} 
ening" arising from the reforms. In the context of the current economic downturn, Standard \& Poor's (2009) writes, "The established fiscal rules have served Sweden well" and, "the Kingdom's substantial fiscal buffers to support its creditworthiness in the current adverse economic environment." Despite the decline in fiscal performance as a result of rising government spending and declining tax revenue, rating agencies believe that the deterioration in public finances will be temporary as the Swedish government has a solid history of fiscal discipline and credible rules in place. One warning from Standard \& Poor's is that Sweden's high tax rates limit its fiscal flexibility and put Sweden in an unfavorable position relative to its peers. Fiscal flexibility, as the simulations below and Bi's (2009) work show, is critical for avoiding sovereign debt risk premia.

\section{A Formal Model of Fiscal Policy and Debt Default}

We employ an extremely simple theoretical model that draws heavily from Bi (2009). Technical details about the model appear in appendix A.

5.1 Sketch of Model A representative household lives in a closed economy and makes choices of consumption, leisure, and savings. We abstract from capital accumulation, so all savings is in the form of government bonds. We also abstract from nominal considerations: bonds are denominated in consumption goods. The government finances its purchases of goods and its lump-sum transfers to the representative household with a proportional tax levied against labor income and with bond sales.

Productivity is an important source of uncertainty in the model. The household knows the stochastic process governing total factor productivity and is aware of the rules governing policy behavior. It uses that information, in conjunction with knowledge of the economy, to form rational expectations over the objects that are important to its decisions.

In contrast to most formal economic models, in this model government debt is risky because the government may choose to default, at least partially, on its liabilities to consumers. Bonds take a simple form: households may buy a bond in year $t$ from the government at the price $q_{t}$; if the bond were risk-free, the government would pay the household one unit of goods in year $t+1$ and the gross rate of return on the bond would be $1 / q_{t}$. Because bonds are risky, if the government partially defaults, the household will receive only a fraction$1-\Delta_{t+1}$, a number between 0 and 1 - of the risk-free payoff. Denote that expected fraction by $E_{t}\left(1-\Delta_{t+1}\right)$, reflecting the fact that when the household buys the bond in year $t$, it does not know what payoff it will receive, since the payoff does not occur until year $t+1$. If the government defaults, the gross rate of return is reduced to $\left(1-\Delta_{t+1}\right) / q_{t}$.

The household faces a fundamental problem that drives most of its economic decisions. 
Random fluctuations in productivity make the household's wage income volatile. If the household always consumed its after-tax income, consumption would also be volatile, with the household binging when times are good and starving when times are bad. But such wild swings in consumption make the household unhappy. ${ }^{9}$ The household solves its fundamental problem of how to keep its consumption smooth by adjusting its savings to buffer itself against income fluctuations. In this simple model, savings take the form of government bond holdings.

The possibility that government may default on its debt adds a dimension of uncertainty against which the household will want to hedge. It does this by factoring the possibility of default into the pricing of government bonds. The more likely is default - or the larger is the anticipated fraction of default - the less the household will be willing to pay for a bond (the lower will be $q_{t}$ ). To word this differently, savers demand a higher rate of return to hold riskier government debt, driving up interest rates economy-wide.

5.2 Government Default and the Fiscal Limit The nature of the risk that the household faces and how the household copes with that risk lie at the heart of the model. Ideally, we would model the intrinsically strategic decision a government reaches when it chooses to default. As noted in the introduction, however, existing political economy models tend to make predictions that are wildly at odds with the observed behavior by governments, such as that governments default at extremely low debt-GDP ratios. In addition, this paper focuses more on how institutional changes to fiscal behavior can alter the probability of default than on the reasons a government might default. For our purposes, it is useful as a first pass to treat the decision to default as exogenous, being determined outside the economic model.

Most taxes distort economic behavior and those distortions have important implications for how much revenue the government collects. Suppose the tax on labor income is increased. If the household's work effort remained unchanged, then the tax base would also remain fixed and tax revenues would rise unambiguously. But the household responds to incentives, so its behavior is unlikely to remain unchanged. Higher income taxes reduce the after-tax return to working, which tends to induce households to work less hard. ${ }^{10}$ The resulting impact on revenue collections is ambiguous, but generally at low tax rates, higher rates raise revenues, while at higher tax rates, higher rates can actually reduce revenues. This phenomenon, dubbed the "Laffer curve," is ubiquitous to environments in which taxes distort, but the

\footnotetext{
${ }^{9}$ They are also inconsistent with the well-established fact that in data consumption is much less volatile than income.

${ }^{10}$ This "substitution effect" may be offset to some extent by the "income effect," by which the household will tend to work harder because higher taxes reduce its income. Empirical evidence tends to suggest that the negative substitution effect outweighs the positive income effect on work effort.
} 
precise details are highly model-specific. ${ }^{11}$

Figure 3 reports a simplified Laffer curve for the model we use. It is simplified because all randomness in the model has been stripped away, so it reports how steady state revenues vary with the labor tax rate. In the figure, the tax rate that maximizes revenues occurs where the curves reach their maximum height [see appendix A.3 for further discussion]. Along the black dotted-dashed line, for example, revenues reach a peak at a tax rate of 70 percent. At tax rates below 70 percent, revenues rise as rates rise, while at tax rates above 70 percent, revenues decline as rates rise. The figure also illustrates that the position of the curve depends, among other things, on how elastic labor supply is with respect to after-tax wages. The more sensitive labor supply is to wages, the lower is the tax rate that maximizes revenues. In the graph, greater sensitivity is associated with a higher Frisch elasticity.

The existence of a Laffer curve carries important implications for fiscal policy. It implies that at any point in time, there is a maximum level of revenues that the government can raise. Setting aside adjustments in government expenditures for the moment, a maximum level of revenues implies a limit to how much debt the government can support. Placed in a dynamic setting, it implies that there is always an upper bound to the expected discounted present value of revenues. Unlike figure 3, actual Laffer curves are both dynamic - changing over time with economic conditions - and stochastic - varying randomly as different shocks hit the economy.

A Laffer curve produces a fiscal limit: if the present value of revenues is bounded, then there is a limit to how much debt it is feasible for the government to service. The dynamic and stochastic nature of the Laffer curve means that the fiscal limit changes over time and that the limit is not a fixed number; it is a probability distribution that depends on many features of the economy — various elasticities determined by private sector behavior, the nature of policy behavior, and the properties of the random disturbances hitting the economy.

In a closed-economy model, any debt that the government sells must be bought by domestic households. But there are also limits to how much debt households are willing to accumulate. If the household saves too much, then it is achieving a lower consumption path than it otherwise could and if it saves too little, then it is not smoothing its consumption as effectively as it might.

If government debt is risk-free, these considerations impose restrictions on the fiscal policies that are consistent with equilibrium, or, what are commonly called "sustainable."

\footnotetext{
${ }^{11}$ Trabandt and Uhlig (2009) use formal economic models to compute Laffer curves for the United States and European Union countries and infer that Denmark and Sweden are on the "slippery side" of their curves, where lower tax rates will raise revenues.
} 
Sustainable policies imply that an intertemporal equilibrium condition, labeled (IEC), must always hold

$$
\begin{aligned}
& \text { Value of Government Bonds }= \\
& \text { Expected Present Value of Future Net Surpluses }
\end{aligned}
$$

where

Net Surpluses $=$ Total Revenues - Government Consumption \& Investment

- Government Transfer Payments

To obtain the fiscal limit, we set tax rates to maximize revenues at in each date and denote the maximum sustainable level of debt in year $t$ by $\mathcal{B}_{t}^{*}$. Then the (IEC) at the fiscal limit is

$$
\mathcal{B}_{t}^{*}=\text { Expected Present Value }\left(T^{*}-\text { Government Expenditures }\right)
$$

The present value in (FL-IEC) depends on the expected path of interest rates when tax rates are always set at the peak of the Laffer curve. Given the model and settings of the parameters of the model, it is possible to compute the distribution of the fiscal limit, $\mathcal{B}_{t}^{*}$, for each year $t$.

5.3 Government Behavior Government in this model behaves quite simply. It sets the levels of spending and transfers "automatically" as a function of the productivity of the economy. This abstraction is intended to mimic the sizeable automatic stabilizers that are built into the Swedish fiscal system, by which spending and transfer payments tend to expand when the economy contracts, and vice versa. We could extend these rules by adding an autonomous aspect to spending and transfers decisions, but this would not alter the basic messages of the paper.

To make this behavior systematic, we posit that transfers in year $t, z_{t}$, respond automatically to productivity with an elasticity of $\alpha^{z}$, while the corresponding elasticity for government spending is $\alpha^{g}$. When expenditure policies are countercyclical, these $\alpha$ 's are negative, so expenditures rise when productivity is low; procyclical policies arise when the $\alpha$ 's are positive.

If spending and transfers are evolving in lockstep with productivity, then taxes must be responding to the state of government debt in order to ensure that the intertemporal equilibrium condition holds. We posit an equally simple, but endogenous rule governing 
the tax rate in the economy: whenever debt adjusted for any default that might occur rises above the long-run level of debt, taxes rise by an amount $\gamma$. This reaction of taxes to debt must be sufficiently strong to guarantee that (IEC) is always satisfied. That is, the policy parameter $\gamma$ must be positive and large enough to stabilize debt. Endogeneity of tax policy is essential for an equilibrium to exist. A fully credible commitment of the government to such a rule, which is also well understood by the private sector, anchors private expectations on policies that are sustainable.

Instead of having only taxes adjust to stabilize debt, one could permit adjustments also on the expenditures side. We do not pursue this avenue in this paper for two reasons. First, in Sweden, as in many European countries, the populace seems more resistant to spending cuts than to tax increases. Second, allowing for adjustments in government expenditures does not alter the basic message of the model, as Bi (2009) shows.

Finally, like the household, the government must satisfy a budget constraint each period. This constraint requires that revenues plus net bond sales must equal total expenditures, inclusive of government purchases, transfer payments, and interest payments on outstanding government debt.

\section{Calibration}

The theoretical model described in section 5 and specified in appendix A cannot be solved analytically, so we turn to numerical solutions. To that end, we need to assign values to the model parameters. This section describes the calibration and appendix B describes the solution method.

6.1 DATA Figure 2 suggests a shift in the level of transfers and government spending occurred between 1992 and 1997. Sweden's financial crisis started in 1992, while the expenditure ceiling on central government spending was introduced in 1997. Claeys (2008) identifies the breakpoint for government spending as the third quarter of 1995 and for transfers as the second quarter of $1996 .^{12}$ We set the breakpoint to be 1997 in order to highlight the comparison before and after the fiscal reform, but different breakpoints do not affect our results qualitatively.

The degree of countercyclical behavior of government spending and transfers, as summarized by the parameters $\alpha^{g}$ and $\alpha^{z}$, is estimated using Swedish data during the period of 1980-2007. Productivity is defined as real GDP per worker, transfers are the sum of social security payments, net capital transfers and subsidies, and government spending is the sum

\footnotetext{
${ }^{12}$ Claeys (2008) uses the ratios of government spending over GDP and lump-sum transfers over GDP, while we use the detrended data of government spending and transfers for reasons explained in section 4 .
} 
of government final consumption and consumption of fixed capital. ${ }^{13}$ Table 1 shows the estimated $\alpha^{g}$ and $\alpha^{z}$ during different periods. The table also reports the average tax rate and the ratios of government spending and transfers to GDP. ${ }^{14}$

\begin{tabular}{l|l|ll}
\hline \hline & $1980-2007$ & $1980-1997$ & $1997-2007$ \\
\hline Response of spending to productivity $\left(\alpha^{g}\right)$ & -0.246 & -0.281 & 0.174 \\
Response of transfers to productivity $\left(\alpha^{z}\right)$ & -1.816 & -1.864 & -1.13 \\
Average tax rate $(\tau)$ & 49.718 & 49.652 & 49.911 \\
Spending-GDP ratio $(g / y)$ & 29.498 & 29.896 & 29.792 \\
Transfers-GDP ratio $(z / y)$ & 21.193 & 22.49 & 19.106
\end{tabular}

Table 1: Swedish Fiscal Data (1980-2007).

Several important changes in Swedish fiscal behavior occurred between the two subperiods. First, there was a sharp decline in the level of transfer payments, from 22.5 to about 19 percent of GDP. Second, government spending shifted from being countercyclical in the early period $\left(\alpha^{g}<0\right)$ to being procyclical in the latter period $\left(\alpha^{g}>0\right)$. Figure 2 also suggests that until the mid-1990s government spending seems to lead debt, whereas in more recent years the relationship more closely mimics that between revenues and debt. This change may be a consequence of the 1997 expenditure ceiling policy.

6.2 Parameter Calibration Table 2 summarizes the calibration of the parameters. We take the model to operate at an annual frequency. The household discount rate is set to be 0.95 , which implies a net annual interest rate of 5.26 percent. Preferences are logarithmic, so both the intertemporal elasticity of substitution and the Frisch labor supply elasticity are unity. We assume that the household spends 25 percent of its time working. The total amount of time and the productivity at steady state are normalized to 1 . The productivity shock is estimated using detrended data of real GDP per worker. Using a Hodrick and Prescott (1997) filter, the shock has persistence of 0.661 and standard deviation of 0.015 .

The degree of countercyclical government spending and lump-sum transfers $\left(\alpha^{g}\right.$ and $\left.\alpha^{z}\right)$, and the transfers-GDP ratio $(z / y)$ are calibrated to pre-crisis data (1980-1997) and postcrisis data (1997-2007) for reasons explained in section 6.1. The steady-state tax rate $(\tau)$ also depends on the regime, but it is calibrated slightly different from the data. Although table 1 shows that the average tax rate is slightly lower in the 1980-1997 period than in the later period, the lower average tax rate is largely driven by a much smaller tax base during

\footnotetext{
${ }^{13}$ Data for real GDP per worker is from Penn World Trade Table (2009).

${ }^{14}$ The average tax rate is defined as total tax revenue (including social security taxes, indirect taxes and direct taxes) as a share of GDP.
} 


\begin{tabular}{l|ll}
\hline \hline Parameter & Value & \\
\hline Discount rate $(\beta)$ & 0.95 & \\
Steady state leisure $(L)$ & 0.75 & \\
Persistence of productivity $(\rho)$ & 0.661 & \\
Standard deviation of productivity $(\sigma)$ & 0.015 & \\
Response of taxes to debt $(\gamma)$ & 0.7 & \\
Spending-GDP ratio $(g / y)$ & 0.28 & \\
\hline \hline & Pre-Crisis & Post-Crisis \\
\hline Response of spending to productivity $\left(\alpha^{g}\right)$ & -0.281 & 0.174 \\
Response of transfers to productivity $\left(\alpha^{z}\right)$ & -1.864 & -1.13 \\
Average tax rate $(\tau)$ & 0.51 & 0.49 \\
Transfers-GDP ratio $(z / y)$ & 0.215 & 0.19
\end{tabular}

Table 2: Calibration of Model Parameters

the crisis from 1993-1997. In addition, the increase of the average tax rate in the later period is likely due to fiscal consolidation, instead of reflecting the long-term trend of tax rates in the post-crisis period. In fact, figure 2 shows that the average tax rate has been declining since 2000. Flodén (2009) and others show that the fiscal reforms reduced the average tax rate by about 6 percentage points from 2003 to 2009. Therefore, we calibrate the average tax rate to be high in the pre-crisis period and low in the post-crisis period. Using data on average tax rates and the debt-GDP ratio, the estimated response of taxes to government debt is around 0.7 , regardless of the period of estimation. The government spending-GDP ratio is calibrated to 0.28 , which is slightly lower than the data, but ensures that the model produces a positive debt-GDP ratio in steady state. ${ }^{15}$

\section{Distribution of the Fiscal Limit and Government Default}

A fiscal limit emerges from this model because a higher distorting tax rate on labor has two countervailing effects. On the one hand, for a given tax base, higher rates raise revenues. But on the other hand, higher rates reduce the after-tax return to labor, inducing agents to consume more leisure, reducing the tax base. For a particular functional form for preferences, we can obtain simple analytical expressions for the resulting Laffer curve. ${ }^{16}$

In a rational expectation equilibrium households will be willing to buy the debt at a riskfree price if they expect that it is feasible for the government to fully honor its obligations.

\footnotetext{
${ }^{15}$ Given a steady-state interest rate, the calibration of government spending and transfers determines the steady-state debt-GDP ratio via the government budget constraint. Applying the OECD's definitions, net debt is gross debt less the financial assets of the government. In Sweden, net debt of the general government differs from the gross debt by a large margin due to pension funds.

${ }^{16}$ Technical details appear in appendix $\mathrm{C}$.
} 
That is, by definition of an equilibrium, government policies are sustainable. Household's expectations are ratified by the presence of a tax rule that stabilizes debt. Most rational expectations analyses of fiscal policy assume that the government is not only able to honor its obligations, but that it is also willing to do so.

This paper distinguishes between the ability and the willingness of the government to execute default-free policies. Even if the government is able to fulfill its promises, it may choose not to. Because that choice is typically driven more by political than economic considerations, we treat the choice as exogenous to prevailing economic conditions. In particular, the decision to default is determined by a random draw, call it $b_{t}^{*}$, from the probability distribution of the fiscal limit, which we approximate with a normal distribution, denoted by $\left.\mathcal{N}\left(\mathcal{B}^{*}, \sigma_{B}^{2}\right)\right)$. In year $t, b_{t}^{*}$ is the threshold level of the debt-GDP ratio. The decision to default is quite simple: if the level of outstanding debt as a share of GDP is greater than or equal to the threshold, then the government defaults by the amount $\Delta_{t}=\delta$; otherwise, the government honors all of its liabilities. $\Delta_{t}$ is the fraction of outstanding debt on which the government defaults. This is the object over which bond holders must form expectations in order to correctly price government bonds.

We shortcut the political process by characterizing it as a random draw from the distribution of the fiscal limit. Nonetheless, the decision to default is constrained by the economic realities that determine the distribution from which the choice is drawn. In this sense, we treat the government's willingness to honor its obligations as a political decision that is not merely a function of the state of the economy. And, naturally, the government's willingness must be constrained by its ability to support its outstanding debt.

As is clear from the derivation of the distribution $\mathcal{B}^{*}$, the properties of the distribution are determined by structural features of the economy - preferences, technologies, exogenous shocks, and government policies. Bi (2009) shows how the fiscal limit depends on an economy's diversification, political uncertainty, the size of government, and the degree of countercyclicality in fiscal policies. These factors can change the mean and/or the dispersion of the distribution. ${ }^{17}$

We turn now to examine how alternative fiscal policies - such as those that have been adopted in Sweden - affect the distribution of the fiscal limit.

\footnotetext{
${ }^{17} \mathrm{Bi}(2009)$ modifies (FL-IEC) to include an additional, possibly time-varying, political discount factor, which reflects the political economy argument that governments and households may discount at different rates. If, for example, the political discount factor is less than 1 , then the resulting distribution for $\mathcal{B}_{t}^{*}$ would shift to the left, implying a lower average fiscal limit. This captures the possibility that political leaders may be more impatient than private economic decision makers.
} 


\section{Policy Experiments}

We treat the model, calibrated to pre-crisis Swedish data (1980-1997), as the baseline. That calibration uses the pre-crisis parameter values in table 2 for policy: government spending and transfers are countercyclical and the average tax rate and share of transfers are "high." We simulate the distribution of the fiscal limit for this baseline calibration and then contrast that distribution to the distributions obtained under alternative calibrations and alternative rules governing spending and transfers policies.

8.1 Alternative Fiscal Policies We interpret the baseline model as reflecting the fiscal situation, including the fiscal limit, in Sweden in the early 1990s when bond rating agencies downgraded Swedish sovereign debt. To this distribution we contrast three alternative fiscal policies that are designed to capture some of the post-crisis reforms:

1. Post-Crisis: Calibrate the average tax rate and the transfers-GDP ratio to the postcrisis parameter values in table 2 for 1997-2007, while assuming that spending and transfers policies are countercyclical, as in the pre-crisis period.

2. Post-Crisis (procyclical): Calibrate the policy parameters to data in the post-crisis period, which implies that government spending is procyclical.

3. Post-Crisis (expenditure ceiling): Adopt the post-crisis calibration for the average tax rate and the share of transfers in GDP, while the cyclical behavior of spending and transfers comes from the pre-crisis period, but add an expenditure ceiling on government spending and transfers. This restricts the government to conduct countercyclical expenditure policies only within some range. We consider one of many ways to implement expenditure ceilings. ${ }^{18}$ The rules we impose operate asymmetrically when spending and transfers policies are countercyclical. During good times, when productivity is high, expenditures will tend to be low and the constraints will not bind. When times are bad and productivity is low, however, expenditures will automatically tend to be higher than normal. If the productivity shock is sufficiently bad, the automatic expansion in expenditures may be bounded above, as the ceiling binds. ${ }^{19}$

Table 3 summarizes the policy settings in the baseline model and in the three alternatives listed above. Case 1 is a counter-factual exercise that asks what the fiscal limit would be if the government were to reduce the tax rate and transfers level to their post-crisis levels,

\footnotetext{
${ }^{18}$ Details are in appendix C.2.

${ }^{19}$ A natural extension to these specifications would add a "discretionary" spending component to the automatic aspects of the rules. In this case, a bad output shock could force the government to choose whether to cut "discretionary" or "non-discretionary" spending.
} 
but continued to follow the pre-crisis countercyclical expenditure rules. Cases 2 and 3 offer two explanations for government expenditures data from 1997 to 2007. Case 2 assumes that government spending shifts from being countercyclical to become procyclical, while case 3 attempts to operationalize the expenditure ceiling rule.

\begin{tabular}{|c|c|c|c|c|}
\hline Parameter & $\begin{array}{l}\text { Pre-Crisis } \\
\text { Baseline }\end{array}$ & $\begin{array}{c}\text { Post-Crisis } \\
\text { Case } 1\end{array}$ & $\begin{array}{c}\text { Post-Crisis } \\
\text { (procyclical) } \\
\text { Case } 2\end{array}$ & $\begin{array}{c}\text { Post-Crisis } \\
\text { (ceiling) } \\
\text { Case } 3\end{array}$ \\
\hline Response of spending to productivity $\left(\alpha^{g}\right)$ & -0.281 & -0.281 & 0.174 & 0.174 \\
\hline Response of transfers to productivity $\left(\alpha^{z}\right)$ & -1.864 & -1.864 & -1.13 & -1.13 \\
\hline Average tax rate $(\tau)$ & 0.51 & 0.49 & 0.49 & 0.49 \\
\hline Transfers-GDP ratio $(z / y)$ & 0.215 & 0.19 & 0.19 & 0.19 \\
\hline
\end{tabular}

Table 3: Alternative Fiscal Policies

8.2 Fiscal Limits Figure 4 compares the distributions of the fiscal limit under the baseline model and the three alternative policies. The top panel plots the histogram for the baseline model. ${ }^{20}$ The median of the fiscal limit - in terms of the debt-output ratio - in the baseline (pre-crisis) calibration is about 80 percent of GDP, but the histogram suggests the distribution has fairly fat tails. Fat tails mean that there is substantial probability of default even at values of the debt-GDP ratio well below the average.

The bottom panel of the figure reports box plots of the fiscal limit distributions for the baseline and the alternatives. Center lines in the boxes are medians, the vertical edges of the boxes are $25^{\text {th }}$ and $75^{t h}$ percentiles, the black vertical lines mark the most extreme values that are not deemed to be outliers, and the outliers are marked by + symbols. The pre-crisis distribution is centered at about a 0.78 debt-output ratio, but the distribution is quite dispersed. Heavy representation of outliers suggests fat tails, with somewhat more probability mass at low debt-GDP ratios. This distribution implies that during the early 1990s Swedish sovereign debt holders may have had good reason to place probability on default, even when debt was at relatively modest levels. This, of course, was the time when Swedish debt was downgraded from $A A A$ to $A A+$.

Fiscal reforms that led to smaller government - in terms of the transfers-GDP ratio and the average level of taxation - shifted the fiscal limit markedly to the right, as the box plot

\footnotetext{
${ }^{20}$ To simulate the fiscal limit, we draw 300 realizations of the productivity shock and compute the equilibrium time paths for all the variables in the model under the assumption that the tax rate is at the peak of the Laffer curve. We discard the first 200 draws as a burn-in period and compute $\mathcal{B}_{1}^{*}$ as the discounted sum of future surpluses, according to (FL-IEC). We repeat this 10,000 times and plot the resulting distribution of $\mathcal{B}_{1}^{*}$.
} 
labeled "Post-Crisis" indicates. The median moved to a bit above 100 percent. Although the tails remain fat, at debt-output ratios of 65 percent or lower the probability of default is essentially zero. ${ }^{21}$

The third box plot, labeled "Post (Procyclical)," uses identical policy settings as the second plot except that government spending switches from counter- to procyclical $\left(\alpha^{g}\right.$ changes from -0.281 to 0.174$)$ and transfers become somewhat less countercyclical ( $\alpha^{z}$ changes from -1.864 to -1.130$)$. Altering the cyclical nature of government expenditures has little effect on the median of the distribution, but dramatically reduces its dispersion, as $\mathrm{Bi}$ (2009) also found. Even debt-GDP ratios of 80 percent imply a negligible probability of default.

Expenditure ceilings have a more subtle influence on the distribution of the fiscal limit, as the fourth box plot shows. Asymmetry in expenditure rules induces asymmetry in the fiscal limit: the upper tail is substantially fatter than the lower tail, shifting risk away from moderate debt-output ratios.

\section{Quantitative Results}

With the distributions of the fiscal limit in hand for various specifications of fiscal behavior, we now turn to simulate the equilibrium of the model to examine the macroeconomic consequences of an environment in which the effective fiscal limit at each date, $b_{t}^{*}$, is a random variable drawn from the model economy's actual fiscal limit distribution.

9.1 Decision Rule The pricing rule for the interest rate on government bonds maps the state of the economy into the yield on bonds, $r_{t}$. Because it is possible for government to default, $r_{t}$ reflects the probability that bond holders place on the government defaulting on debt next period. For simplicity, we plot $r$ as a function of the debt-output ratio, denoted by $r(b)$ in figure 5, fixing productivity at its steady-state level. The model delivers the sideways $S$ relationship between risk premia and government debt: at low debt-GDP ratios, risk premia are very small; over certain ranges, however, premia rise rapidly with debt, before flattening out at high levels of debt.

Figure 5 compares the pricing rules under alternative policy specifications. The top panel compares the pre-crisis and post-crisis cases in which transfers and spending policies behave countercyclically. In the absence of default, the risk-free interest rate rises with debt, but only very slightly, so the sharp run-ups in the decision rule are attributable almost entirely to risk. In the pre-crisis baseline calibration, a sizable risk premium emerges when the debtGDP ratio reaches about 65 percent. In contrast, under the post-crisis calibration - which entails a smaller government - the pricing function is flat until the debt-GDP ratio rises to

\footnotetext{
${ }^{21}$ A similar result that "smaller" government raises the fiscal limit appears in Bi (2009).
} 
95 percent. This result suggests that reducing the average level of taxes and transfers may contribute importantly to avoiding risk premia on government bonds.

The bottom panel compares the three post-crisis cases - countercyclical government spending (dashed line), procyclical government spending (solid line), and an expenditures ceiling (dotted dashed line). Both procyclical spending and an expenditure ceiling extend the insensitivity of interest rates to debt to higher levels of debt, relative to countercyclical spending without a ceiling. Procyclical spending policy makes the function appreciably steeper, so within a certain range of debt-output ratios, small increases in debt can lead to rapid increases in interest rates. An expenditure ceiling can subdue the emergence of default risk premium compared to either of the other two alternative policies by shifting probability mass in the fiscal limit from low to high values of debt, as the bottom panel of figure 4 shows. Taken together, the results for procyclical spending and expenditures ceiling policies provide some support for the argument that such policies can cushion the Swedish economy from risk premia on government debt.

The figure has important implications for empirical work seeking to find a relationship between debt and interest rates. Nonlinearity means that over a wide range of "low" levels of debt, interest rates are quite insensitive to changes in debt. As debt levels rise, though, there is a range over which interest rates move substantially with changes in debt. At very high levels of debt, it is possible for the relationship to once again be quite weak. An empirical finding that the correlation between interest rates and debt is small when debt is low cannot be extrapolated to higher levels of debt. Moreover, since the fiscal limit, and therefore the relationship between interest rates and debt, is time varying, it can be quite tricky to make accurate predictions of how rates will change with debt.

9.2 Simulation We now simulate the model using as the driving process the actual time path of the productivity shock from detrended Swedish data on labor productivity. The economy is assumed to be in steady state in 1990 and is then hit by a sequence of negative productivity shocks from 1991-1997, with no additional shocks hitting the economy from 1998 onward. ${ }^{22}$

Figure 6 reports the equilibrium paths of variables in the baseline model when actual data on output per worker (labeled "Productivity") from 1991 to 1997 is fed into the model. These bad output disturbances begin in period 6 in the figure, continue through period 12, after which productivity decays smoothly back to steady state. Solid lines allow for the possibility of default, when the default rate is 10 percent, and dashed lines come from

${ }^{22}$ Specifically, in the data in $1990 \log \left(A_{t} / A\right)=0.018$ and the values of $\left(A_{t}\right)$ from 1991 to 1997 are $(0.9758,0.9628,0.9404,0.9671,0.9770,0.9653,0.9700)$. To simulate the model we feed in these values for the first 7 years and then allow $A_{t}$ to decay according to the autoregressive process in (2). 
imposing a default rate of 0 . Differences between the lines arise entirely from the possibility that the government may default. The upper right panel, labeled "Government Debt," plots the paths of equilibrium debt, the realized path of the stochastic default threshold (jagged solid line showing $\left.b_{t}^{*}\right)$ drawn from $\mathcal{N}\left(\mathcal{B}^{*}, \sigma_{b}^{2}\right)$-and two-standard-deviation bands around the mean of the distribution for the fiscal limit (straight dashed lines). Whenever the path of debt crosses the realized threshold, the government defaults by 10 percent on its outstanding debt.

Bad productivity shocks raise government spending and transfers through their automatic countercyclical response, increasing government debt substantially. Higher debt brings forth higher tax rates, which ensure that government policy is sustainable. Because goods today are scarce relative to goods in the future, the real interest rate rises sharply. Low productivity and high tax rates discourage work effort, reducing both output and consumption. Reinforcing the elevated level of debt are the higher interest payments induced by both higher principle and higher interest rates. Along the transition path, debt remains close to the lower two-standard-deviation band. Although in this simulation no default occurs, the possibility of default keeps the interest rate elevated for an extended period, as government debt retires back to steady state only very slowly. Note that the possibility of default has deleterious effects on hours worked and consumption, though in this simulation, those additional impacts are quite small.

Figure 6 also illustrates an important lesson for empirical studies. Risk premia, driven by increases in default probabilities, can emerge even when no actual default occurs. For this reason, it may not be productive to restrict empirical analyses of the relationship between interest rates and fiscal policy to samples in which governments have defaulted.

The interest rate in figure 6 is a short, one-period rate. Most government debt carries a longer maturity. Longer maturities lead to the possibility that long-term interest rates might provide an "early-warning signal" of default fears. It is straightforward to use the theoretical model to price longer-maturity bonds according to an asset-pricing formula to obtain the prices for a bond sold in period $t$ that matures in period $t+n$. Longer maturity bond prices will tend to move before shorter maturity bond prices in response to news about defaults farther into the future.

Figure 7 illustrates that long-term bonds give advance warnings of sovereign defaults in a severe recession. ${ }^{23}$ Expected high government indebtedness in the future results in a rise in current risk premia of long-term bonds, even when the premia on short-term bonds show no increase at all. The longer the bond maturity, the earlier the default risk premia emerge.

Figure 8 examines how the economy would perform in the face of the same sequence

\footnotetext{
${ }^{23}$ This exercise conditions on the same sequence of bad productivity shocks as in figure 6 .
} 
of bad productivity shocks as in figure 6, but under the three alternative fiscal policies. Each alternative calibrates steady state transfers and taxes to be lower than in the pre-crisis environment that figure 6 depicts. In all case, because the post-crisis calibration shifts the distribution of the fiscal limit sharply to the right, as shown in figure 4, the run-up in debt stays well below the tail of the distribution and policy remains essentially risk-free. This result suggests that the fiscal reforms may cushion Swedish debt from the wrath of financial markets, should the economy be hit again by shocks like those in the early 1990s.

Procyclical government spending (dashed blue lines) and the expenditures ceiling (solid black lines) have similar consequences for the paths of hours worked, consumption, tax rates, interest rates, and debt, although their implications for the paths of spending and transfers are quite different. The similarities arise because the procyclical spending policy lowers spending, while transfers continue to behave countercyclically and rise. Both components of expenditures rise under the ceiling policy, but the total change in spending and transfers under the two policies is approximately the same. With nearly identical consequences for debt expansion and tax rates, the two policies affect the macro economy is very similar ways.

Countercyclical spending policy, in contrast, has important different effects on the economy (dotted dashed red lines). In this case, both spending and transfers rise sharply in response to the economic downturn, pushing debt higher. More debt carries with it higher tax obligations, which suppress work effort and consumption. Although debt rises more, it remains well away from the fiscal limit, ensuring little, if any, risk premia.

\section{Concluding Remarks}

This paper is but a first step toward studying the tradeoffs between short-run fiscal stimulus and long-run sustainability. The next step is to extend the model to allow expansions in government spending and transfers to stimulate aggregate demand and overall economic activity. As an empirical matter, the jury is still out on whether government spending multipliers are large enough to rationalize the use of fiscal stimulus through spending measures. But we know it is possible to write down theoretical models in which government spending is efficacious. Extending the present setup to include a beneficial role for countercyclical fiscal policy will give the analysis broader applicability.

Another extension that is important for conclusions about both fiscal stimulus and sustainability is to model monetary policy. Recent work has found that interactions between monetary and fiscal policies - particularly the possibility that monetary policy may be operating at or near the lower bound on nominal interest rates - can play an important role in determining the size of fiscal multipliers [Christiano et al. (2009), Davig and Leeper (2009), Eggertsson (2009)]. Moreover, in the presence of a fiscal limit, monetary policy's ability to 
control inflation can be jeopardized [Sims (2004, 2009), Cochrane (2009), Davig et al. (2010), Leeper (2009b)].

When examining an economy like Sweden's, it is natural to embed this analysis in a small open economy. Such an extension of the present model is immediate and unlikely to alter the major results. First, the distribution of the fiscal limit is independent of whether the economy is a closed or open. So long as the government collects distortionary taxes, there exists dynamic Laffer curve and, therefore, there is a distribution of the fiscal limit. Second, both international and domestic investors care about default risk, which is the expected default rate in the bond pricing equation. One difference between international and domestic investors arises because the saving decision of domestic investors is also affected by future tax policy, as the government's future liabilities may change in the face of default. The magnitude of the second effect depends on the elasticity of intertemporal substitution. Logarithmic utility ensures that the second effect is trivial, and a risk premium decomposition shows that 95 percent of the risk premium comes from the expected default rate. This implies that the quantitative results will stay almost the same even if the economy were to open up. On the other hand, the results could be sensitive to the assumption of openness if the government issues nominal debt.

It is unlikely, however, that such extensions will alter a key conclusion from the present analysis: the right kinds of fiscal reforms - specifically, the adoption of certain classes of fiscal rules - can shift the economy's fiscal limit in important ways and dramatically reduce the likelihood that sovereign debt will be assessed a risk premium, even in the face of bad economic shocks like those that hit Sweden in the 1990s.

There is a growing body of work on fiscal rules in dynamic stochastic general equilibrium models in which the maintained assumption is that government debt is risk-free [Kumhof and Laxton (2009, 2008), Leith and Wren-Lewis (2005, 2006), Kirsanova et al. (2006b)]. There is room for extending this analysis to models in which government debt may be risky. One question to address is: to what class of economic disturbances is a given set of rules robust in the sense of ensuring that policy mimics the risk-free outcome?

As the results of sections 8 and 9 make clear, alternative fiscal policies can have quantitatively important consequences for an economy's fiscal limit. The distribution of the fiscal limit, in turn, has consequences for risk premia and economic performance. It is useful to study implementable and verifiable fiscal rules and trace out their implications for the distribution of fiscal limits across countries.

Finally, it is worthwhile, to the extent possible, to use formal models to study the consequences of various proposals for the formulation of fiscal policy councils of the kind that 
Sweden and Hungary, among other countries, have adopted. ${ }^{24}$ Simon Wren-Lewis and his co-authors have made substantial progress along these lines [Kirsanova et al. (2006a), WrenLewis (2008)]. It is likely that embedding the possibility of sovereign debt default will strengthen those arguments in favor of subjecting government fiscal decisions to independent scrutiny.

\footnotetext{
${ }^{24}$ See, for example, von Hagen and Harden (1994), Wyplosz (2005, 2008), Calmfors (2009), Leeper (2009a).
} 

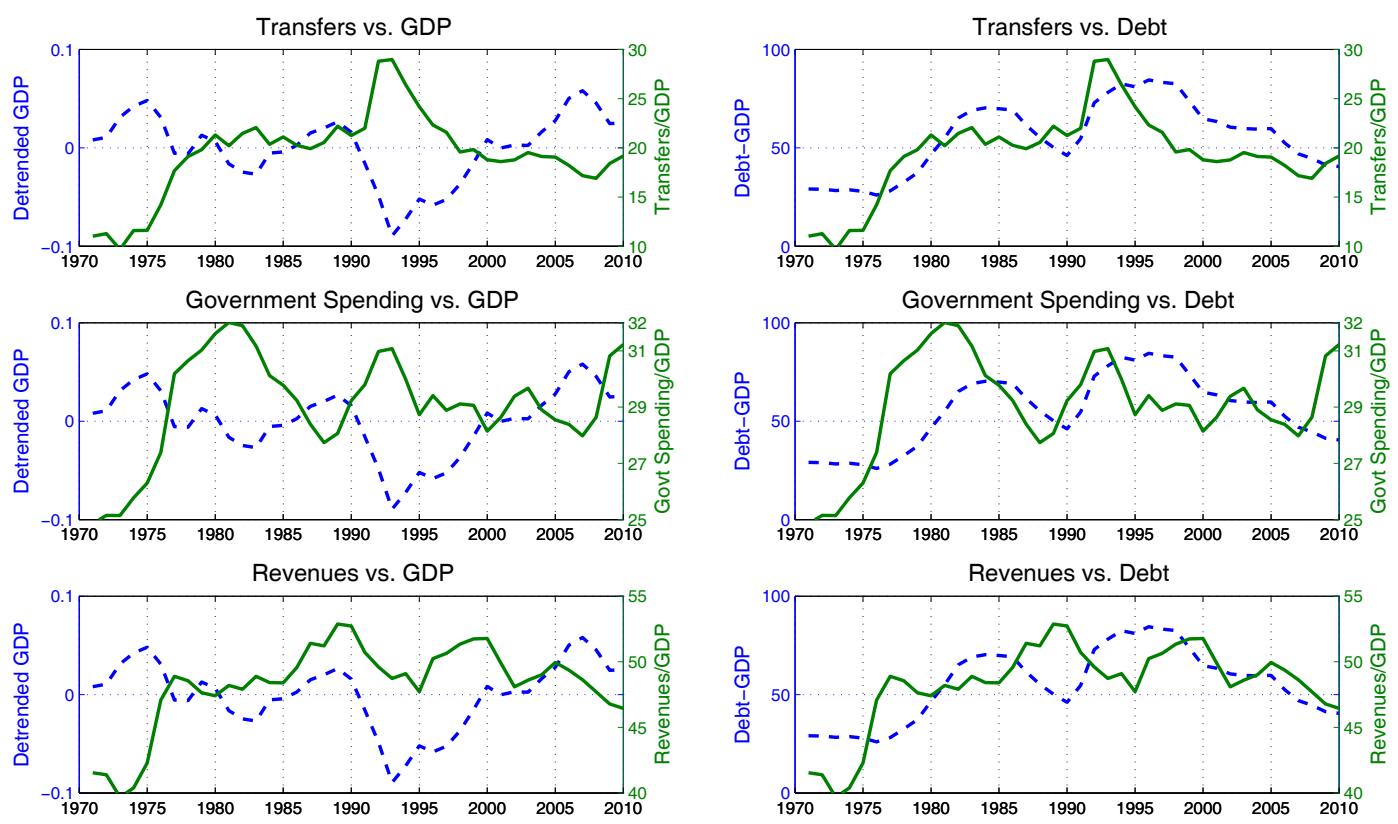

Figure 1: Swedish data. Left panels plot three fiscal variables - transfers, government spending, and revenues as shares of GDP-(solid lines, measured on right axes) and detrended real GDP (dashed lines, measured on left axes). Right panels plot the fiscal variables and the debt-GDP ratio. 

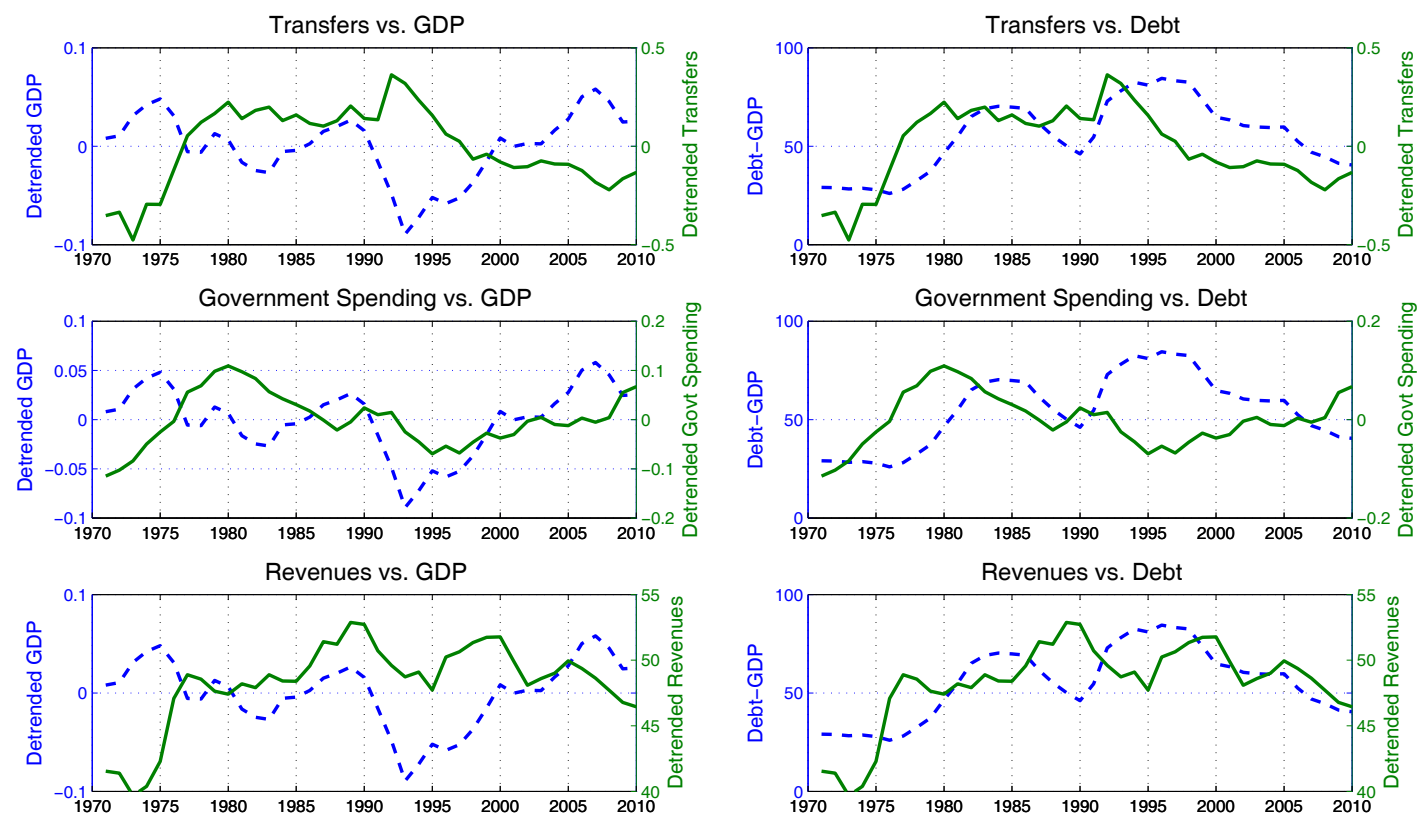

Figure 2: Swedish data. Left panels plot detrended values of three fiscal variables - transfers, government spending, and revenues - (solid lines, measured on right axes) and detrended real GDP (dashed lines, measured on left axes). Right panels plot the detrended fiscal variables and the debt-GDP ratio. 




Figure 3: Simple Laffer curves from steady state version of the theoretical model. Plotted for three elasticities of labor supply, ranging from relatively inelastic (0.5) to relatively elastic (3.0). 

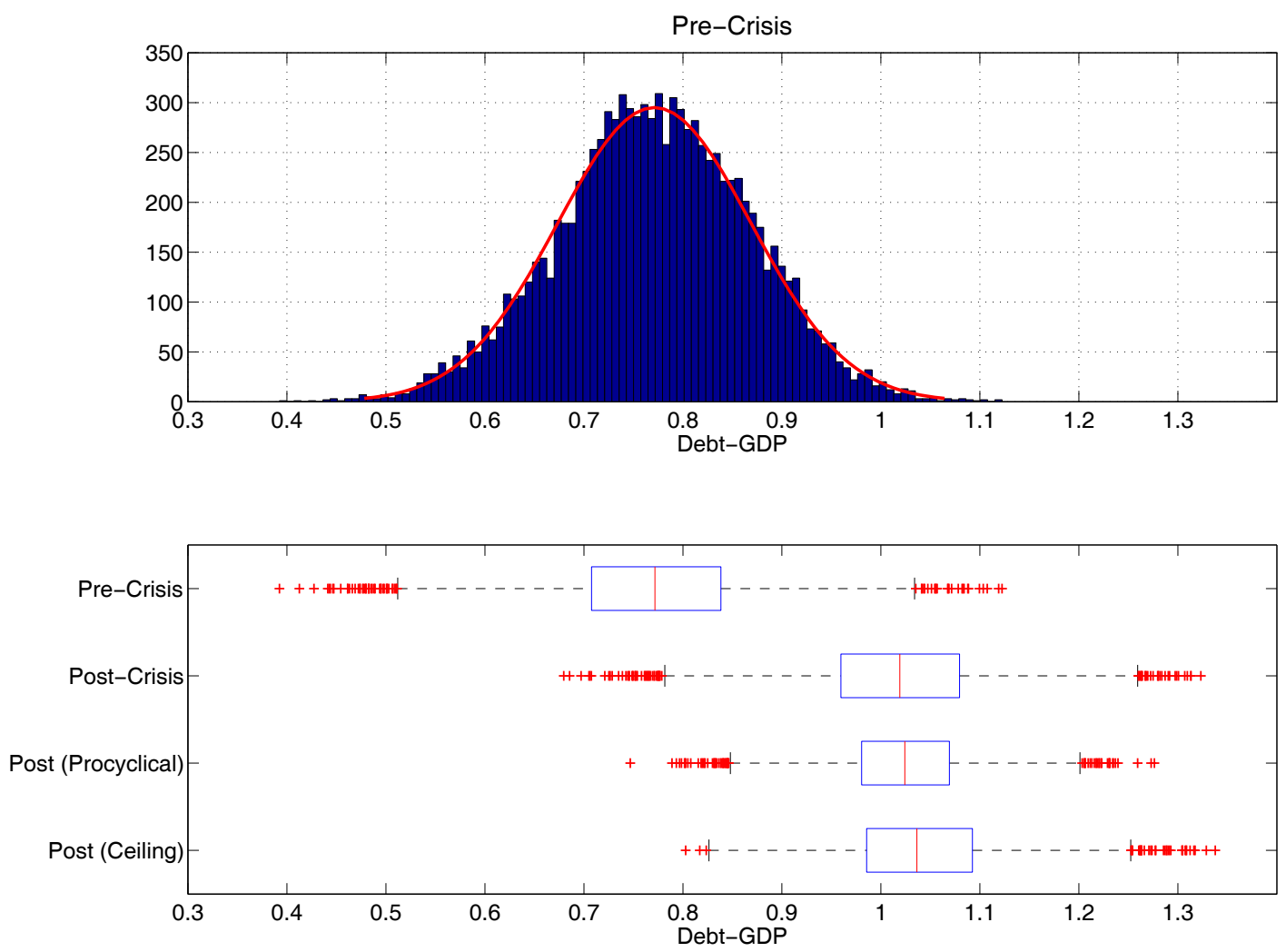

Figure 4: Distribution of the fiscal limit. Top panel plots the distribution of fiscal limit under the pre-crisis calibration; bottom panel compares the distribution under the precrisis calibration and three alternative calibrations: post-crisis, post-crisis with procyclical government spending and post-crisis with expenditure ceiling. 
r(b): Pre-Crisis vs. Post-Crisis

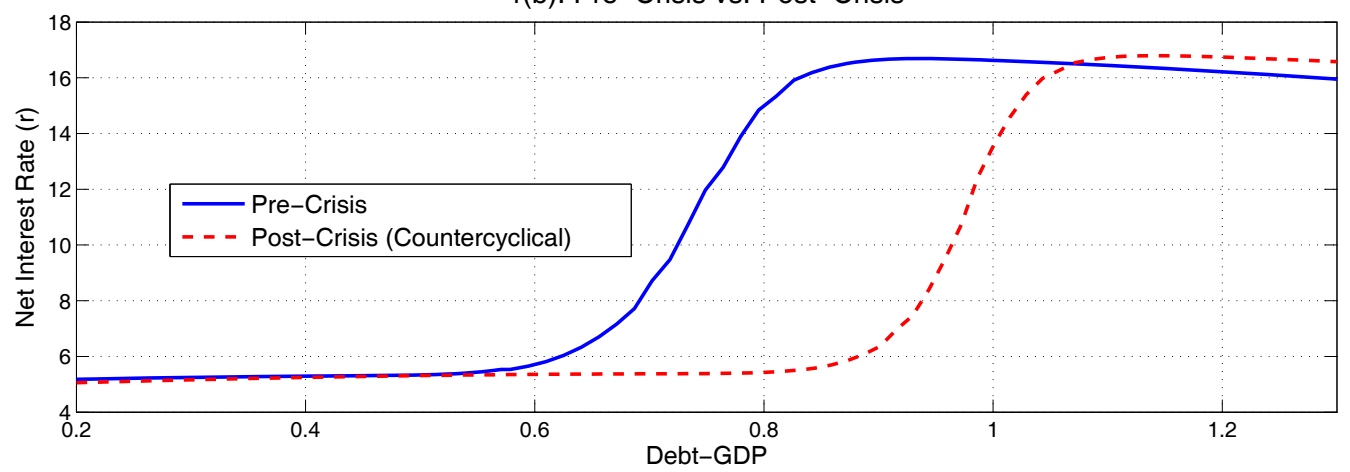

r(b): Post-Crisis Alternative Fiscal Policies

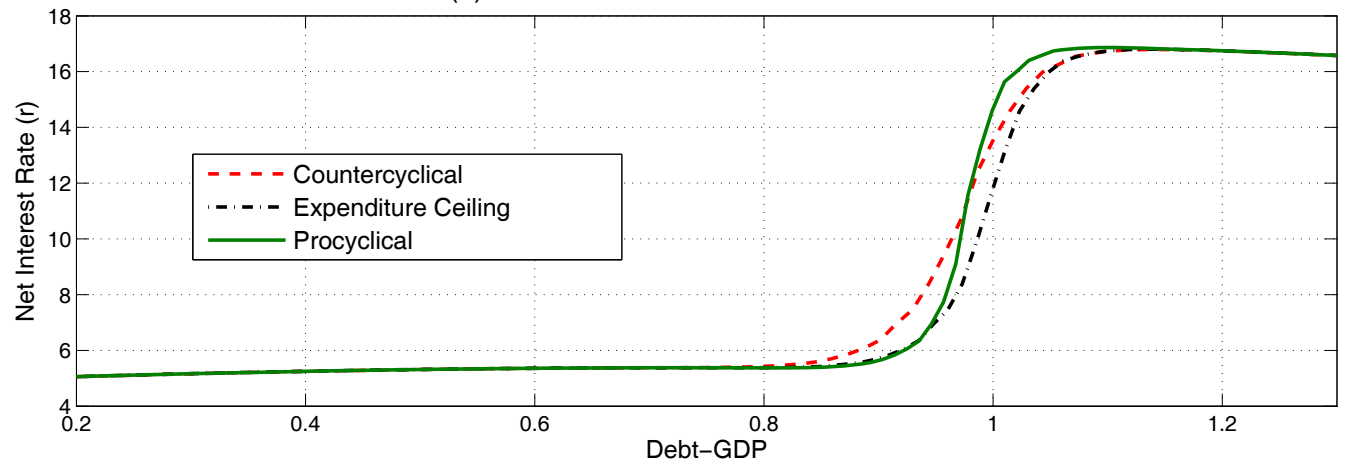

Figure 5: Net interest rate as a function of debt-GDP ratio. Pricing rules under different calibrations when technology is at its steady-state level. Top panel compares the pre-crisis case to the post-crisis case with countercyclical government spending. Bottom panel compares three post-crisis cases: countercyclical government spending, an expenditure ceiling, and procyclical government spending. 

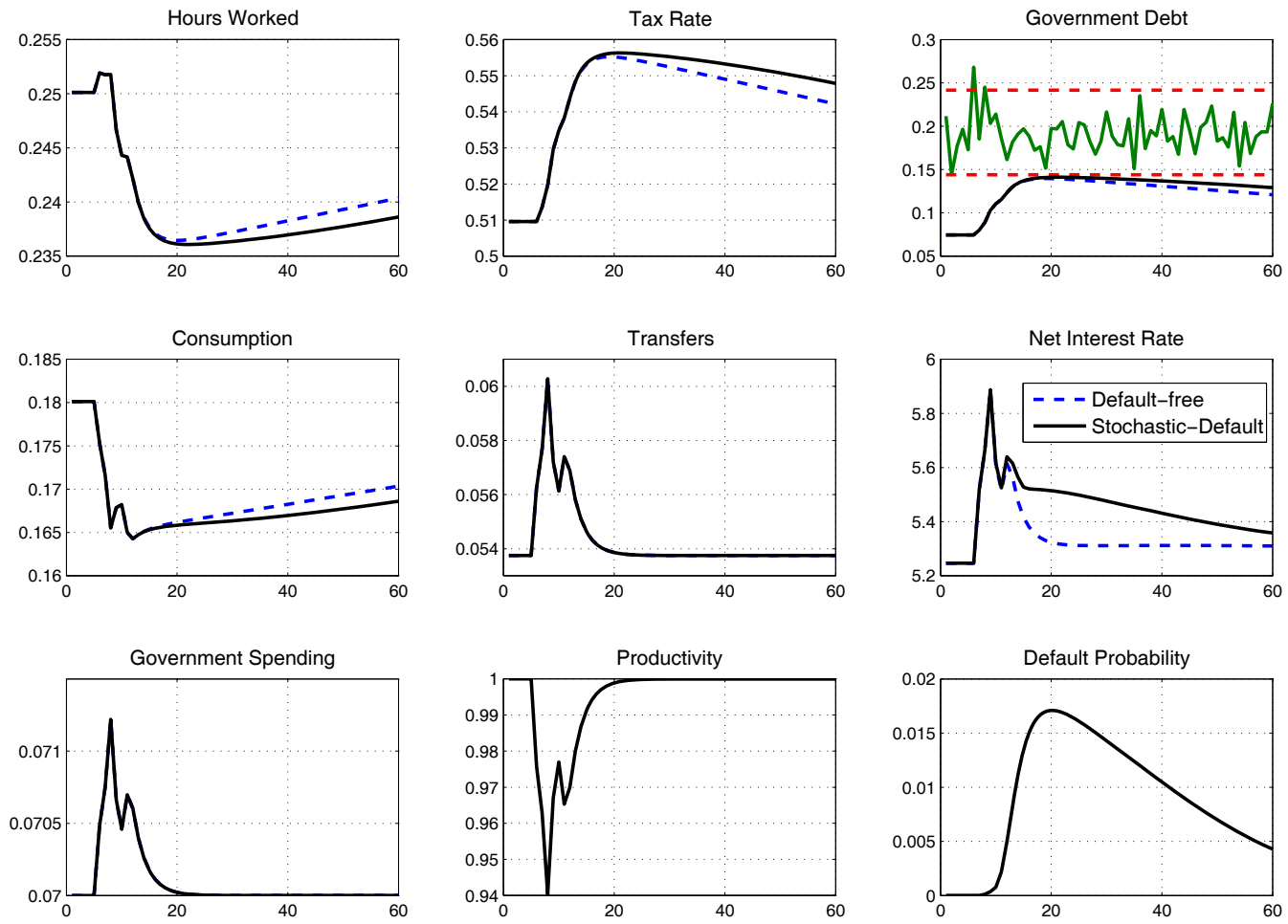

Figure 6: Effects of a sequence of negative technology shocks under pre-crisis calibration. Path of technology for 1991-1997 from Swedish data is fed into model, assuming the economy is in steady state in 1990. Dashed blue lines represent a stochastic default scheme $(\delta=0.1)$ and solid black lines represent a default-free scheme $(\delta=0)$. Time units in years. 
Risk Premia of Long-term Bonds

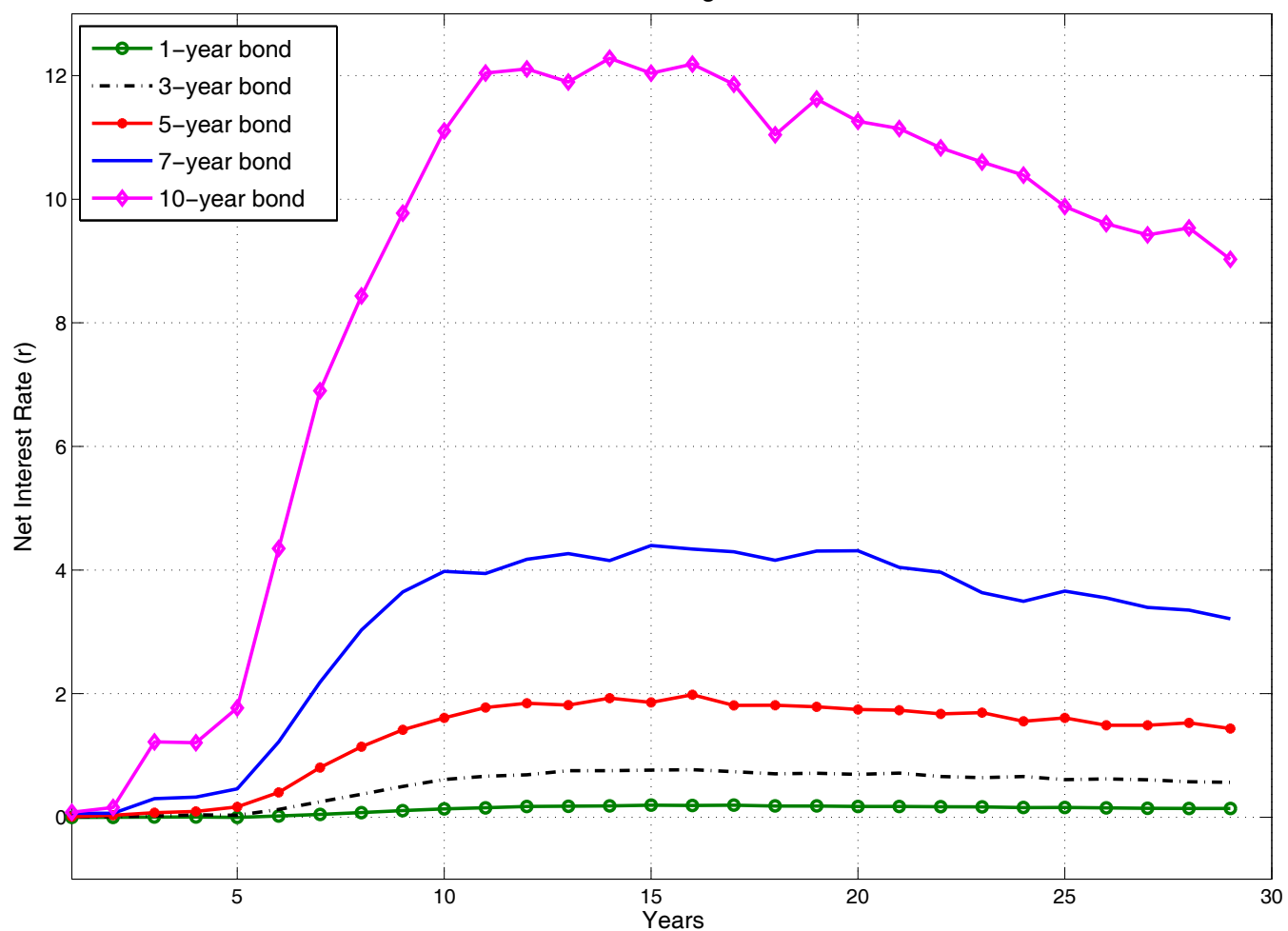

Figure 7: Risk premia on long-term bonds with different maturities computed using a simulation, conditioning on the path of technology shocks in figure 6 under pre-crisis calibration. 

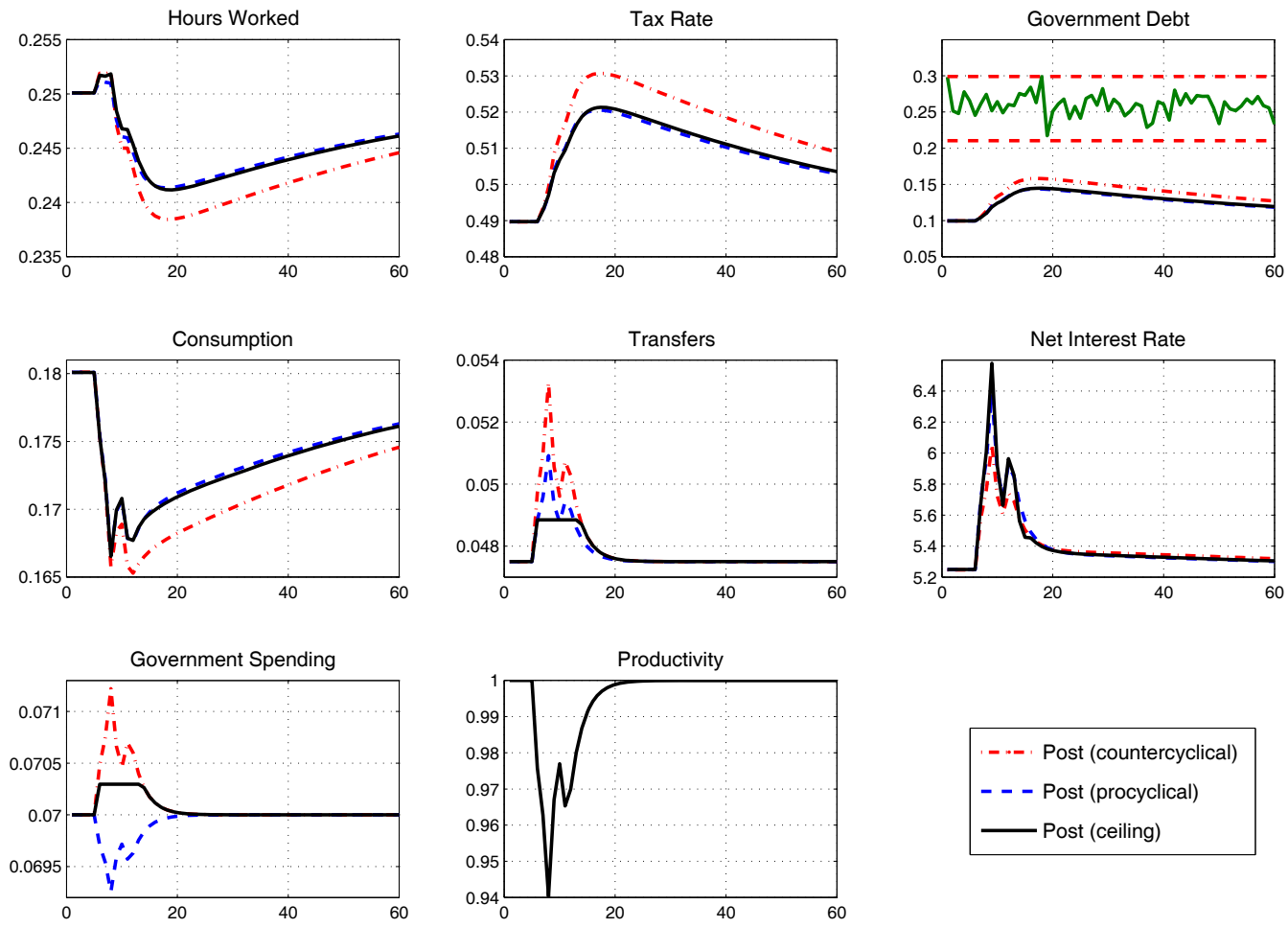

Figure 8: Effects of a sequence of negative technology shocks under alternative fiscal policies. Path of technology for 1991-1997 from Swedish data is fed into calibrated model, assuming the economy is in steady state in 1990. Countercyclical government spending (dotted dashed red lines); procyclical government spending (dashed blue lines); government expenditure ceiling (solid black lines). Time units in years. 


\section{A The Formal Model}

Goods are produced using a technology that is linear in hours worked, $1-L_{t}$, whose productivity is determined by the realization of productivity, $A_{t}$. The economy's production technology is

$$
y_{t}=A_{t}\left(1-L_{t}\right)
$$

where $y_{t}$ is GDP and we assume that the technology shock follows $\mathrm{AR}(1)$ process

$$
\ln \frac{A_{t}}{A}=\rho \ln \frac{A_{t-1}}{A}+u_{t} \quad u_{t} \sim \mathcal{N}\left(0, \sigma^{2}\right)
$$

with $0 \leq \rho<1$.

Total supply of goods at each date is consumed, either by households, $c_{t}$, or by the government, $g_{t}$, so the aggregate resource constraint for the economy is

$$
c_{t}+g_{t}=A_{t}\left(1-L_{t}\right)
$$

A.1 Household Consumers receive after-tax income, $A_{t}\left(1-\tau_{t}\right)\left(1-L_{t}\right)$, lump-sum transfers, $z_{t}$, and payoffs from government bonds they purchased in the previous period, $b_{t}^{d}$. With these sources of income, consumers buy goods and new government bonds, $b_{t}$, that sell at price $q_{t}$. Because the government may choose to default, at least partially, on its liabilities to consumers, $b_{t}^{d}=\left(1-\Delta_{t}\right) b_{t-1}$, where $\Delta_{t} \in[0,1]$ is the fraction of outstanding liabilities on which the government defaults, so $b_{t}^{d}$ denotes post-default government liabilities. We date post-default liabilities at $t$ because, although the liabilities are carried over from $t-1$, the value of $\Delta_{t}$ is not known until period $t$.

The representative household behaves competitively and chooses consumption, leisure, $L_{t}$, and bond purchases, $b_{t}$, in order to maximize

$$
E_{0} \sum_{t=0}^{\infty} \beta^{t} u\left(c_{t}, L_{t}\right), \quad 0<\beta<1,
$$

subject to its budget constraint

$$
A_{t}\left(1-\tau_{t}\right)\left(1-L_{t}\right)+z_{t}-c_{t}=b_{t} q_{t}-\underbrace{\left(1-\Delta_{t}\right) b_{t-1}}_{b_{t}^{d}}
$$

taking as given prices and policies, $\left\{\tau_{t}, z_{t}, q_{t}, \Delta_{t}\right\}$. $E_{t}$ is the mathematical expectation that is conditional on time $t$ information, consisting of all variables dated $t$ and earlier, including the sovereign default information at time $t . \quad \beta$ is the discount factor. $u(c, L)$ is strictly 
increasing and strictly concave in household consumption and leisure. The household's firstorder conditions are

$$
\begin{aligned}
\frac{u_{L}(t)}{u_{c}(t)} & =A_{t}\left(1-\tau_{t}\right) \\
q_{t} & =\beta E_{t}\left(\left(1-\Delta_{t+1}\right) \frac{u_{c}(t+1)}{u_{c}(t)}\right)
\end{aligned}
$$

where we employ the notation $u_{z}(s) \equiv \partial u\left(c_{s}, L_{s}\right) / \partial z_{s}$. Expression (6) equates the household's marginal rate of substitution between consumption and leisure to the after-tax return to labor (equivalent to the after-tax wage rate). Dynamics enter the household's saving decision because bonds bought today do not pay off until the future. This dynamic appears in equation (7), which links the government bond price to the household's expectation of sovereign default in the next period, $\Delta_{t+1}$.

Random fluctuations in technology make the household's income volatile. Concave utility implies that the household seeks to smooth its consumption plan by saving in periods when income is high and dissaving when income is low. In this simple model, the household smooths its consumption in the face of income fluctuations by adjusting its bond holdings.

Naturally, optimizing households will want to avoid either over- or under-accumulating government bonds. For example, if the household saves too much, then it is achieving a lower consumption path and, therefore, lower utility, than it otherwise could. This consideration leads to the household's transversality condition

$$
\lim _{T \rightarrow \infty} E_{t} Q_{t, t+T} b_{t+T}=0
$$

where $Q_{t, t+T} \equiv \frac{q_{t}}{1-\Delta_{t}} \frac{q_{t+1}}{1-\Delta_{t+1}} \cdot \ldots \cdot \frac{q_{t+T}}{1-\Delta_{t+T}}$. Because the transversality condition, (8), is one of the necessary and sufficient conditions for optimization, its satisfaction is part of the definition of an equilibrium.

Transversality has important implications. An immediate implication derives from substituting from (7) for the q's in (8) to obtain

$$
\lim _{T \rightarrow \infty} \beta^{T+1} E_{t} \frac{u_{c}(t+T+1)\left(1-\Delta_{t+T+1}\right)}{u_{c}(t)\left(1-\Delta_{t}\right)} b_{t+T}=0
$$

Expression (9) reveals that the prices the household uses to value government debt depend on both the household's marginal rate of substitution and on the expected default fraction. We discuss further implications below. 
A.2 Government Government in this model behaves as an automaton: unlike the household, which solves an explicit optimization problem, the government obeys simple ad hoc rules in setting its fiscal instruments and must ensure that its choices satisfy its budget constraint

$$
\tau_{t} A_{t}\left(1-L_{t}\right)+b_{t} q_{t}=\underbrace{\left(1-\Delta_{t}\right) b_{t-1}}_{b_{t}^{d}}+g_{t}+z_{t}
$$

The bond contract is not enforceable. At time $t$, the government may partially default on its outstanding liabilities, $b_{t-1}$, at the rate of $\Delta_{t}$. The decision to default is quite simple: if the level of debt outstanding exceeds some threshold, $b_{t}^{*}$, then the government defaults by the fraction $\delta$; otherwise, the government fully honors its debt commitments. The default fraction is given by

$$
\Delta_{t}= \begin{cases}0 & \text { if } b_{t-1}<b_{t}^{*} \\ \delta & \text { if } b_{t-1} \geq b_{t}^{*}\end{cases}
$$

where $b_{t}^{*}$ is a random draw from the distribution of fiscal limit, $\mathcal{N}\left(\mathcal{B}^{*}, \sigma_{B}^{2}\right)$. We return to a detailed discussion of the fiscal limit below. The random nature of $b_{t}^{*}$ reflects the fact that debt renegotiation involves political considerations from which we abstract and which we do not model. This simple rule for determining whether the government (partially) defaults on its debt makes clear that this paper does not address the strategic issue of why the government may choose to default. From the government's perspective, default is costless in this model, so there is no scope to examine the tradeoffs the government faces when it decides to default.

Government spending and tax decisions are governed by time-invariant rules. Cyclical patterns in government spending and lump-sum transfers are induced by rules that allow transfers and purchases to respond systematically with technology, which is the source of cycles in the model.

$$
\begin{aligned}
& \log \frac{z_{t}}{z}=\alpha^{z} \log \frac{A_{t}}{A} \\
& \log \frac{g_{t}}{g}=\alpha^{g} \log \frac{A_{t}}{A}
\end{aligned}
$$

Variables without subscripts in (11) and (12) denote steady state values, so these rules are written in terms of deviations from steady state. When the $\alpha$ parameters are positive (negative), transfers and spending are procyclical (countercyclical). ${ }^{25}$

The tax policy rule sets deviations of the income tax rate from steady state as a function

\footnotetext{
${ }^{25}$ More commonly, cyclicality is defined in terms of comovements with output, rather than technology. In the present model, there is no important economic distinction between output and technology, whereas the use of technology is computationally easier.
} 
of deviations of post-default liabilities from steady state debt

$$
\tau_{t}-\tau=\gamma\left(b_{t}^{d}-b\right)
$$

To bring debt back to steady state, taxes must adjust enough to both service any new debt issuances and eventually retire those new issuances. This assumption about tax policy behavior appears to be consistent with the casual empirical evidence offered in figures 1 and 2.

Throughout the paper we maintain the tax policy in (13), even when we consider alternative policies for how transfers and government spending are determined.

A.3 The Model's Laffer Curve Prescott (2006) argues that a Frish elasticity of 3 is consistent with macro data, while studies using micro data suggest an estimation in the range of 0 to 1 . Trabandt and Uhlig (2009) survey this literature.

In the benchmark model, preferences are assumed to be $u\left(c_{t}, L_{t}\right)=\log c_{t}+\phi \log L_{t}$, where $L_{t}$ is leisure. Let $n_{t}$ denote the labor supply, then $n_{t}=1-L_{t}$. The Frisch elasticity is defined as

$$
\frac{d n_{t}}{d w_{t}} \frac{w_{t}}{n_{t}}=\frac{1-n}{n}
$$

where $n$ is the labor supply at steady state. Since we assume the household spends 25 percent of its time working $(n=0.25)$, the Frish elasticity is 3 in the benchmark model.

Alternatively, if we assume preferences to be $u\left(c_{t}, L_{t}\right)=\log c_{t}+\phi L_{t}^{1+\frac{1}{\psi}}$, then the Frisch elasticity is

$$
\frac{d n_{t}}{d w_{t}} \frac{w_{t}}{n_{t}}=\psi \frac{1-n}{n}
$$

If $\psi=0.33$ and $n=0.25$, then the Frisch elasticity is 1 .

Figure 3 compares the model's Laffer curves for three different Frisch elasticities. Even though a lower elasticity leads to a larger revenue-maximizing tax rate, the Frisch elasticity has only a modest impact on the overall position of the Laffer curve.

\section{B The Solution Method}

We solve the model using the monotone map method described by Coleman (1991) and Davig (2004). The procedure conjectures candidate decision rules that reduce the system of equations characterizing the equilibrium to a set of expectation first-order difference equations and then iterates to find a fixed point in the space of decision rules. The state of 
the economy in this model consists of the realization of the technology shock, $A_{t}$, and the post-default level of liabilities, $b_{t}^{d}$. Let $\psi_{t}=\left\{b_{t}^{d}, A_{t}\right\}$ denote the state at $t$. Then the decision rule maps $\psi_{t}$ into the endogenous state variable, $b_{t} \cdot{ }^{26}$ The equilibrium mapping is denoted by the function $b_{t}=f^{b}\left(\psi_{t}\right)$.

The complete model can be reduced to a single equation:

$$
\begin{array}{r}
\frac{b_{t}^{d}+g\left(\psi_{t}\right)+z\left(\psi_{t}\right)-\tau\left(\psi_{t}\right) A_{t}\left(1-L\left(\psi_{t}\right)\right)}{f^{b}\left(\psi_{t}\right)} \\
=\beta E_{t}\left\{\left(1-\Delta\left(f^{b}\left(\psi_{t}\right), A_{t+1}, b_{t+1}^{*}\right)\right) \frac{u_{c}\left(f^{b}\left(\psi_{t}\right), A_{t+1}, b_{t+1}^{*}\right)}{u_{c}\left(\psi_{t}\right)}\right\}
\end{array}
$$

Given a realization of the state, $\psi_{t}$ and expectations at date $t$ of technology, $A_{t+1}$ and the draw of the fiscal limit, $b_{t+1}^{*}$, next period, the monotone map solves for the decision rule, $f^{b}\left(\psi_{t}\right)$, that solves (16). The expectation on the right-hand side is evaluated using numerical quadrature, integrating over the conditional probability distributions for technology and the fiscal limit.

\section{Computation of Fiscal Limit}

Household consumption and labor supply depend only on the income tax rate and the exogenous state variable, $A_{t}$ (recall that $g_{t}$ is a function of $A_{t}$ ). When the utility function is $u(c, L)=\log c+\phi \log L$, the household's first-order conditions can be written as

$$
\begin{aligned}
1-L_{t} & =\frac{A_{t}\left(1-\tau_{t}\right)+\phi g_{t}}{A_{t}\left(1+\phi-\tau_{t}\right)} \\
c_{t} & =\frac{\left(A_{t}-g_{t}\right)\left(1-\tau_{t}\right)}{1+\phi-\tau_{t}}
\end{aligned}
$$

Tax revenues, $T_{t}$, are

$$
\begin{aligned}
T_{t} & =\tau_{t} \frac{A_{t}\left(1-\tau_{t}\right)+\phi g_{t}}{1+\phi-\tau_{t}} \\
& =(1+2 \phi) A_{t}-\phi g_{t}-\left(A_{t}\left(1+\phi-\tau_{t}\right)+\frac{(1+\phi) \phi\left(A_{t}-g_{t}\right)}{1+\phi-\tau_{t}}\right)
\end{aligned}
$$

Tax revenues reach their the maximum level, $T_{t}^{\max }$, when the tax rate reaches the peak of the Laffer curve. Denote the tax rate that maximizes revenue by $\tau_{t}^{\max }$. These critical tax

\footnotetext{
${ }^{26}$ Note the state variable $b_{t}^{d}=\left(1-\Delta_{t}\right) b_{t-1}$ incorporates two dimensions of information: the default threshold at time $t, b_{t}^{*}$, and the pre-default level of government liabilities, $b_{t-1}$.
} 
parameters can be obtained analytically as

$$
\begin{aligned}
\tau_{t}^{\max } & =1+\phi-\sqrt{\frac{(1+\phi) \phi\left(A_{t}-\mathcal{G}\left(A_{t}\right)\right)}{A_{t}}} \\
T_{t}^{\max } & =(1+2 \phi) A_{t}-\phi \mathcal{G}\left(A_{t}\right)-2 \sqrt{(1+\phi) \phi A_{t}\left(A_{t}-\mathcal{G}\left(A_{t}\right)\right)}
\end{aligned}
$$

$\mathcal{G}\left(A_{t}\right)$ shows that $g_{t}$ is a function of $A_{t}$. At each date $t$, the peak of the Laffer curve is determined by preference parameters and the realizations of technology. In this sense, the fiscal limit is both model-specific and dynamic [see, for example, Trabandt and Uhlig (2009)].

The resulting fiscal limit at $t$, denoted $\mathcal{B}_{t}^{*}$, is the expected sum of the discounted fiscal surplus if the government collects the maximum level of tax revenue from time $t$ on.

$$
\mathcal{B}_{t}^{*}=E_{t} \sum_{h=1}^{\infty} \beta^{h} \frac{u_{c}^{\max }(t+h)}{u_{c}^{\max }(t)}\left(T_{t+h}^{\max }-g_{t+h}-z_{t+h}\right)
$$

where $u_{c}^{\max }(\cdot)$ denotes marginal utility evaluated at the allocations associated with $\tau_{t}^{\max }$. The stochastic default threshold is a random draw from $\mathcal{N}\left(\mathcal{B}^{*}, \sigma_{B}^{2}\right)$.

C.1 Technical Explanation of Fiscal Limit It is important to emphasize that the fiscal limit is independent of the equilibrium conditions of the model.

The size of tax adjustment parameter, $\gamma$, determines the existence of unique equilibrium. For a given set of structural parameters and shock process, there exists an adjustment threshold, denoted as $\gamma^{\text {min }}$, such that any $\gamma$ below the threshold may lead to indeterminacy.

However, the fiscal limit, $\mathcal{B}_{t}^{*}$, does not depend on $\gamma$. Equation (21) shows that other than the structural parameters of the model, $\tau_{t}^{\max }$ only depends on the realization of technology at time $t$. So do $c_{t}^{\max }, L_{t}^{\max }$ and $T_{t}^{\max }$, which denote consumption, labor supply and tax revenue evaluated at the allocations associated with $\tau_{t}^{\max }$. Mathematically,

$$
\begin{aligned}
1-L_{t}^{\max } & =\frac{A_{t}\left(1-\tau^{\max }\left(A_{t}\right)\right)+\phi \mathcal{G}\left(A_{t}\right)}{A_{t}\left(1+\phi-\tau^{\max }\left(A_{t}\right)\right)} \\
c_{t}^{\max } & =\frac{\left(A_{t}-\mathcal{G}\left(A_{t}\right)\right)\left(1-\tau^{\max }\left(A_{t}\right)\right)}{1+\phi-\tau^{\max }\left(A_{t}\right)} \\
T_{t}^{\max } & =(1+2 \phi) A_{t}-\phi \mathcal{G}\left(A_{t}\right)-2 \sqrt{(1+\phi) \phi A_{t}\left(A_{t}-\mathcal{G}\left(A_{t}\right)\right)}
\end{aligned}
$$

Therefore, (22) shows that the resulting fiscal limit, $\mathcal{B}_{t}^{*}$, only depends on $A_{t}$ and structural parameters. It is irrelevant to the government tax policy and, therefore, the tax adjustment parameter $\gamma$.

Note that the default scheme we consider in this paper is different from a "pure" endoge- 
nous default which is an outcome when transversality condition fails to hold under given current and expected future fiscal policy. In other words, such a "pure" endogenous default may arise if the current government liability, $b_{t}$, surpasses the sum of discounted future fiscal surplus under given current and expected future fiscal policy, denoted as $\mathcal{B}_{t}^{\text {end }}$.

$$
\mathcal{B}_{t}^{\text {end }}=E_{t} \sum_{h=1}^{\infty} \beta^{h} \underbrace{\frac{u_{c}(t+h)}{u_{c}(t)}\left(T_{t+h}-g_{t+h}-z_{t+h}\right)}_{\text {Depend on } \gamma}
$$

The problem with the "pure" endogenous default is that such defaults will never happen in equilibrium in our model - if $\gamma$ is sufficiently large, then the government never defaults; if $\gamma$ is smaller than $\gamma^{\text {min }}$, then there is indeterminacy.

C.2 Alternative Fiscal Policies We interpret the baseline model as reflecting the fiscal limit in Sweden in the early 1990s when bond rating agencies downgraded Swedish sovereign debt. To this distribution we contrast three alternative fiscal policies that are designed to capture some of the post-crisis reforms:

1. Post-Crisis: Calibrate $\tau$ and $z / y$ to the post-crisis parameter values in table 2 for 1997-2007, while assuming $\alpha^{g}$ and $\alpha^{z}$ take on the same countercyclical values as in the pre-crisis period.

2. Post-Crisis (procyclical): Calibrate $\alpha^{g}, \alpha^{z}, \tau$ and $z / y$ to data in the post-crisis period, which implies that government spending is procyclical.

3. Post-Crisis (expenditure ceiling): Adopt the post-crisis calibration $-\tau$ and $z / y$ take values from 1997-2007, while $\alpha^{g}$ and $\alpha^{z}$ take values from pre-crisis period-but add an expenditure ceiling on government spending and transfers. This restricts the government to conduct countercyclical expenditure policies to within some range. Specifically, posit the expenditure ceiling rules

$$
\begin{aligned}
& \log \frac{g_{t}}{g}=\alpha^{g} \min \left(\log \frac{A_{t}}{A},-\sigma\right) \\
& \log \frac{z_{t}}{z}=\alpha^{z} \min \left(\log \frac{A_{t}}{A},-\sigma\right)
\end{aligned}
$$

where $\sigma$ is one standard deviation for the technology shock. 


\section{REFERENCES}

Aguiar, M. and Gopinath, G. (2006). Defaultable debt, interest rates and the current account. Journal of International Economics, 69 (1), 64-83.

Alesina, A., De Broeck, M., Prati, A. and Tabellini, G. (1992). Default risk on government debt in OECD countries. Economic Policy, 15, 427-63.

Ardagna, S. (2009). Financial markets' behaviour around episodes of large changes in the fiscal stance. European Economic Review, 53, 37-55.

-, Caselli, F. and Lane, T. (2007). Fiscal discipline and the cost of public debt service: Some estimates for OECD countries. B.E. Journal of Macroeconomics, 7 (1).

Arellano, C. (2008). Default risk and income fluctuations in emerging economies. American Economic Review, 98 (3), 690-712.

Barth, J., Iden, G., Russek, F. and Wohar, M. (1991). The effects of federal budget deficits on interest rates and the composition of domestic output. In R. G. Penner (ed.), The Great Fiscal Experiment, Urban Institute Press.

Bayoumi, T., Goldstein, M. and Woglom, G. (1995). Do credit markets discipline sovereign borrowers? Evidence from U.S. states. Journal of Money, Credit and Banking, 27 (4), 1046-1059.

Bernoth, K., von Hagen, J. and Schuknecht, L. (2006). Sovereign risk premiums in the European government bond market. GESY Discussion Paper No. 151.

BI, H. (2009). Sovereign risk premia, fiscal limits and fiscal policy. Manuscript, Indiana University.

Boije, R. and Fischer, J. (2006a). Fiscal indicators in a rule-based framework. Manuscript, Swedish Ministry of Finance.

— and - (2006b). The Swedish budget 'model': A genuine beauty or in need of a face lift? In J. Ayuso-i Casals, S. Deroose, E. Flores and L. Moulin (eds.), The Role of Fiscal Rules and Institutions in Shaping Budgetary Outcomes, European Commission, pp. 297-336.

Borg, A. (2009). Kommenterar till Finanspolitiska rådets rapport 2009. Presentation, Swedish Ministry of Finance, 11 May. 
Calmfors, L. (2009). Swedish fiscal policy: Meeting with IMF country mission. Presentation Slides, June 8.

Canzoneri, M. B., Cumby, R. E. and DibA, B. T. (2002). Should the European Central Bank and the Federal Reserve be concerned about fiscal policy? Mimeo, Georgetown University.

Chinn, M. and Frankel, J. (2005). The euro area and world interest rates. Department of Economics, University of California, Santa Cruz Working Paper Series, No. 1031.

Christiano, L. J., Eichenbaum, M. and Rebelo, S. (2009). When is the government spending multiplier large? Manuscript, Northwestern University.

Claeys, P. (2008). Rules and their effects on fiscal policy in Sweden. Swedish Economic Policy Review, 15 (1), 7-47.

Cochrane, J. H. (2009). Understanding fiscal and monetary policy in 2008-2009. Manuscript, University of Chicago.

Codogno, L., Favero, C. and Missale, A. (2003). Yield spreads on EMU government bonds. Economic Policy, 18 (37), 503-532.

Coenen, G., Erceg, C., Freedman, C., Furceri, D., Kumhof, M., Lalonde, R., Laxton, D., Lindé, J., Mourougane, A., Muir, D., Mursula, S., De Resende, C., Roberts, J., Roeger, W., Snudden, S., Trabandt, M. and in't Veld, J. (2009). Effects of fiscal stimulus in structural models. Manuscript, IMF.

Cogan, J. F., Cwik, T., Taylor, J. B. and Wieland, V. (2009). New Keynesian versus old Keynesian government spending multipliers. ECB Working Paper No. 1090.

Coleman, W. J., II (1991). Equilibrium in a production economy with an income tax. Econometrica, 59 (4), 1091-1104.

Congressional Budget Office (2009a). An Analysis of the President's Budgetary Proposals for Fiscal Year 2010. Washington, D.C.: CBO, June.

Congressional Budget Office (2009b). The Long-Term Budget Outlook. Washington, D.C.: CBO, June.

Cwik, T. and Wieland, V. (2009). Keynesian government spending multipliers and spillovers in the euro area. Manuscript, Goethe University Frankfurt. 
DAi, Q. and Philippon, T. (2006). Fiscal policy and the term structure of interest rates. Manuscript, University of North Carolina at Chapel Hill.

Davig, T. (2004). Regime-switching debt and taxation. Journal of Monetary Economics, $51(4), 837-859$.

— and LEePER, E. M. (2009). Monetary-fiscal policy interactions and fiscal stimulus. NBER Working Paper No. 15133.

- , — and Walker, T. B. (2010). 'Unfunded liabilities' and uncertain fiscal financing. Forthcoming in Carnegie-Rochester Confrence Series on Public Policy, NBER Working Paper No. 15782.

Dumas, J.-P. (2004). Medium-term fiscal framework: Experience from Sweden. Http://jpdumas.com/.

Eaton, J. and Gersovitz, M. (1981). Debt with potential repudiation: Theoretical and empirical analysis. Review of Economic Studies, 48 (2), 289-309.

- - - and Stiglitz, J. E. (1986). The pure theory of country risk. European Economic Review, 30 (3), 481-513.

EgGertsson, G. (2009). Can a tax cut deepen the recession? Manuscript, Federal Reserve Bank of New York.

Engen, E. M. and Hubbard, R. G. (2004). Federal government debt and interest rates. AEI Working Paper No. 105.

FlodÉn, M. (2009). Automatic fiscal stabilizers in Sweden 1998-2009. SSE/EFI Working Paper Series in Economics and Finance No. 719.

Gale, W. G. and Orszag, P. R. (2003). Economic effects of sustained budget deficits. National Tax Journal, LVI (3), 463-485.

Haugh, D., Ollivaud, P. and Turner, D. (2009). What drives sovereign risk premia? An analysis of recent evidence from the euro area. OECD Economics Department Working Papers No. 718.

Heppke-Falk, K. and Hüfner, F. (2004). Expected budget deficits and interest rate swap spreads - evidence for France, Germany and Italy. Deutsche Bundesbank Discussion Paper No. 40. 
Hodrick, R. J. and Prescott, E. C. (1997). Postwar U.S. business cycles: An empirical investigation. Journal of Money, Credit and Banking, 29 (1), 1-16.

Jonung, L. (2009). The Swedish model for resolving the banking crisis of 1991-93: Seven reasons why it was successful. European Economy, Economic Papers 360, European Commission, Brussels.

- and Hagberg, T. (2005). How costly was the crisis of the 1990s? A comparative analysis of the deepest crises in Finland and Sweden over the last 130 years. European Economy, Economic Papers 224, European Commission, Brussels.

Kirsanova, T., Leith, C. and Wren-Lewis, S. (2006a). Optimal debt policy, and an institutional proposal to help in its implementation. Paper invited for presentation at DG EcFIn of the European Commission, Brussels November 2006 on "The Role of National Fiscal Rules and Outcomes in Shaping Budgetary Outcomes".

-, Satchi, M., Vines, D. and Wren-Lewis, S. (2006b). Optimal fiscal policy rules in a monetary union. Forthcoming in Journal of Money, Credit and Banking.

Kumhof, M. and Laxton, D. (2008). Implementable fiscal policy rules for open economies. Manuscript, International Monetary Fund.

- and - (2009). Chile's structural fiscal surplus rule: A model-based evaluation. IMF Working Paper WP/09/88.

Laubach, T. (2003). New evidence on the interest rate effects of budget deficits and debt. Journal of the European Economic Association, 7 (4), 858-885.

Leeper, E. M. (2009a). Anchoring fiscal expectations. Reserve Bank of New Zealand Bulletin, 72 (3), 7-32.

- (2009b). Anchors away: How fiscal policy can undermine "good" monetary policy. Manuscript, Indiana University.

-, Plante, M. and Traum, N. (2009). Dynamics of fiscal financing in the United States. Forthcoming in Journal of Econometrics, NBER Working Paper No. 15160.

Leith, C. and Wren-Lewis, S. (2005). Fiscal stabilization and fiscal institutions. Oxford Review of Economic Policy, 21 (4), 584-597.

— and - (2006). The costs of fiscal inflexibility. World Economic \& Finance Programme Working Paper No. 0005. 
Lindh, Y. and Luungman, G. (2007). Fiscal rules and the scope for stabilisation policythe case of Sweden. Manuscript, IMF.

Ljungman, G. (2008). Expenditure ceilings-A survey. IMF Working Paper WP/08/02.

Lønning, I. M. (2000). Default premia on European government debt. Review of World Economics, 136 (2), 259-283.

MendozA, E. G. and Yue, V. Z. (2008). A solution to the default risk-business cycle disconnect. NBER Working Paper No. 13861.

Prescott, E. C. (2006). Nobel lecture: The transformation of macroeconomic policy and research. Journal of Political Economy, 114 (2), 203-235.

Reinhart, C. M. and Rogoff, K. S. (2008). Banking crises: An equal opportunity menace. NBER Working Paper No. 14587.

Romer, C. and Bernstein, J. (2009). The Job Impact of the American Recovery and Reinvestment Plan. Washington, D.C.: Obama Transition Team, January 9.

Sims, C. A. (2004). Fiscal aspects of central bank independence. In H.-W. Sinn, M. Widgren and M. Kothenburger (eds.), European Monetary Integration, Cambridge, MA: MIT Press, pp. 103-116.

- (2009). Fiscal/monetary coordination when the anchor cable has snapped. Slides, Princeton University, May 22.

Standard \& Poor's (1997). S\&P revises Sweden's foreign currency outlook to stable. RatingsDirect, April 18.

Standard \& Poor's (2009). Sweden (Kingdom of). RatingsDirect, April 30.

Sveriges Riksbank (2008). Monetary Policy in Sweden. Stockholm: Sveriges Riksbank.

Swedish Fiscal Policy Council (2009a). Comments on the 2010 budget bill. Stockholm, Sweden, October.

Swedish Fiscal Policy Council (2009b). Swedish fiscal policy: Report of the Swedish Fiscal Policy Council, 2009. Stockholm, Sweden, May.

Swedish Ministry of Finance (2001). An account of fiscal and monetary policy in the 1990s. Government Bill 200/01:100 Annex 5, Stockholm. 
Swedish Ministry of Finance (2009). Anders Borg kommenterar Finanspolitiska rådets rapport. 11 May Press Release, http://www.regeringen.se/sb/d/119/a/126138.

Trabandt, M. and Uhlig, H. (2009). How far are we from the slippery slope? The Laffer curve revisited. NBER Working Paper No. 15343.

Traum, N. and YANG, S.-C. S. (2009). Investigating the crowding out effect of U.S. government debt. Manuscript, Indiana University.

Uhlig, H. (2009). Some fiscal calculus. Manuscript, University of Chicago.

von Hagen, J. and Harden, I. J. (1994). National budget processes and fiscal performance. European Economy Reports and Studies, 3, 311-418.

Wetterberg, G. (2009). Money and Power: From Stockholms Bano 1656 to Sveriges Riksbank Today. Stockholm: Sveriges Riksbank in cooperation with Atlantis.

Wren-Lewis, S. (2008). The case for a UK fiscal council. Slides available at http://www.economics.ox.ac.uk/members/simon.wren-lewis/.

Wyplosz, C. (2005). Fiscal policy: Institutions versus rules. National Institute Economic Review, 191, 64-78.

- (2008). Fiscal policy councils: Unlovable or just unloved? Swedish Economic Policy Review, 15, 173-192. 